\title{
Reassessment of branched Lithophyllum spp. (Corallinales, Rhodophyta) in the Caribbean Sea with global implications
}

\author{
Jazmin J. Hernandez-Kantun ${ }^{1 *}$, Paul Gabrielson ${ }^{2}$, Jeffery R. Hughey ${ }^{3}$, Laura Pezzolesi ${ }^{4}$, Fabio Rindi $^{4}$, \\ Nestor M. Robinson ${ }^{5}$, Viviana Peña ${ }^{6}$, Rafael Riosmena-Rodriguez ${ }^{5} \uparrow$, Line Le Gall ${ }^{7}$ and Walter Adey ${ }^{1}$ \\ ${ }^{1}$ Botany Department, National Museum of Natural History, Smithsonian Institution, MRC 166 PO Box 37012 , \\ Washington, DC 20013, USA \\ ${ }^{2}$ Department of Biology and Herbarium, Coker Hall CB 3280, University of North Carolina, Chapel Hill, \\ Chapel Hill, NC 27599-3280, USA \\ ${ }^{3}$ Division of Mathematics, Science, and Engineering, Hartnell College, 411 Central Avenue, Salinas, CA 93901, USA \\ ${ }^{4}$ Dipartimento di Scienze della Vita e dell'Ambiente, Università Politecnica delle Marche, \\ Via Brecce Bianche, 60131 Ancona, Italy \\ ${ }^{5}$ Programa de Investigación en Botánica Marina, Departamento de Biología Marina, \\ Universidad Autónoma de Baja California Sur, La Paz, Baja California Sur 23080, Mexico \\ ${ }^{6}$ BIOCOST Research Group, Departamento de Bioloxía Animal, Bioloxía Vexetal e Ecoloxía, Facultade de Ciencias, \\ Universidade da Coruña, Campus de A Coruña, 15071, A Coruña, Spain; Equipe Exploration, Espèces et Evolution, \\ Institut de Systématique, Évolution, Biodiversité ISYEB - UMR $7205-C N R S, M N H N, U P M C, E P H E$, \\ Muséum National d'Histoire Naturelle, Sorbonne Universités, 57 rue Cuvier, CP 39 75005, Paris, France; \\ Phycology Research Group, Ghent University, Krijgslaan 281, Building S8, 9000, Ghent, Belgium \\ ${ }^{7}$ Equipe Exploration, Espèces et Evolution, Institut de Systématique, Évolution, Biodiversité ISYEB - UMR $7205-C N R S$, \\ MNHN, UPMC, EPHE, Muséum National d'Histoire Naturelle, Sorbonne Universités, \\ 57 rue Cuvier, CP 39 75005, Paris, France
}

\begin{abstract}
Plastid-encoded $r b c \mathrm{~L}$ and $p s b \mathrm{~A}$ sequences from branched, Caribbean Sea Lithophyllum specimens indicate that four species are present, not one. Short (263 base pairs) $r b c \mathrm{~L}$ sequences from an isolectotype of L. kaiseri (Gulf of Suez) and the holotypes of $L$. congestum, L. daedaleum and L. platyphyllum (Caribbean Sea) show that L. congestum and L. daedaleum are conspecific with L. kaiseri, the last having nomenclatural priority. Lithophyllum platyphyllum, currently considered a synonym of $L$. congestum, is recognised as a valid species. Lithophyllum stictaeforme, originally described from the Mediterranean Sea, is not conspecific with L. kaiseri (as L. congestum) as previously suggested. Lithophyllum neocongestum sp. nov. and L. pseudoplatyphyllum sp. nov. are proposed. Together with L. platyphyllum, these three branched species are so far endemic to the Caribbean Sea. This is the first report, documented by DNA sequence data, of a coralline species (L. kaiseri) widespread through the tropical Indo-West Pacific Oceans, Red Sea and Caribbean Sea.

Key Words: Algal ridges, Lithophyllum congestum, Lithophyllum daedaleum, Lithophyllum kaiseri, Lithophyllum neocongestum sp. nov., Lithophyllum platyphyllum, Lithophyllum pseudoplatyphyllum sp. nov., psbA, rbcL, Sequencing type material, Systematics
\end{abstract}

\section{INTRODUCTION}

Three species of Lithophyllum Philippi are currently recognised in the Caribbean Sea: Lithophyllum prototypum (Foslie) Foslie (type locality: St. Croix, US Virgin Islands) is an epiphytic, epizoic and epilithic thin crust reported from Florida, Bermuda and the Greater and Lesser Antilles [Littler \& Littler 2000, as Titanoderma prototypum (Foslie) Woelkerling, Y.M.Chamberlain \& P.C.Silva]; L. incrustans Philippi (type locality: Sicily, Italy) is a thick crust epizoic on shells likely incorrectly said to occur in Puerto Rico (Ballantine et al. 2011), whereas L. congestum (Foslie) Foslie (type locality: St. Barthélemy, French Antilles, West Indies) is a conspicuously branched, epizoic and epilithic reef-

\footnotetext{
* Corresponding author (jaz1083@gmail.com).

$\dagger$ Deceased.

DOI: $10.2216 / 16-7.1$

(C) 2016 International Phycological Society.
}

forming species reported throughout the Greater and Lesser Antilles (Steneck \& Adey 1976; Adey 1998; Littler \& Littler 2000). This latter species, which is the focus of this research, is together with Porolithon pachydermum (Foslie) Foslie the dominant nongeniculate coralline species comprising algal ridges throughout the Caribbean Sea (Adey 1978). They are regarded as bioengineers, providing habitat heterogeneity (Steneck \& Adey 1976; Adey 1998). Moreover, branching $L$. congestum is also abundant in trottoir structures at tide levels rimming rocky shores of many Caribbean islands (Adey 1986). On the basis of a series of transplant experiments, Steneck and Adey (1976) showed that L. congestum presented large variation in gross morphology in different habitats. As a consequence, they placed in synonomy, under L. congestum, two other branched Lithophyllum species with type localities in the Caribbean Sea. These two species were L. daedaleum Foslie \& M.Howe (type locality: Salinas Bay, Puerto Rico) and L. platyphyllum (Foslie) Foslie (type locality: St. Martin, French Antilles, West Indies). 
Recently, Basso et al. (2014, 2015) assessed branched Lithophyllum species that possess trichocytes from the Red Sea and Indian and Pacific oceans, using both DNA sequences and morphoanatomical characters from type and field-collected material. They concluded that: (1) L. affine (Foslie) Foslie (type locality: Massawa, Eritrea, Red Sea), L. kaiseri (Heydrich) Heydrich (type locality: El Tor, Egypt, Gulf of Suez), L. kotschyanum Unger (type locality: Persian Gulf) and L. subreduncum Foslie (type locality: Hawaii) are distinct species; (2) two new species needed to be recognized, L. yemenense D.Basso, Caragnano, L.Le Gall \& Rodondi and L. socotraense D.Basso, Caragnano, L.Le Gall \& Rodondi; and (3) L. okamurae f. subplicatum (Foslie) P.C.Silva (type locality: Samoa) represents a distinct species, L. subplicatum (Foslie) D.Basso, Caragnano, L.Le Gall \& Rodondi. In contrast to Basso et al. (2015), who recognized several species on the basis of DNA sequences and morphoanatomical characters, Tamega et al. (2014), on the basis only of morphoanatomical characters, placed $L$. congestum in synonymy with L. stictaeforme (Areschoug) Hauck (type locality: Mediterranean Sea), and suggested that both species were conspecific with L. kotschyanum. However, it is well known that L. stictaeforme has a distinctive lamellate gross morphology (e.g. Athanasiadis 1999) and has never been reported to form branched thalli in the Mediterranean, in contrast with the branched morphology of L. congestum (Steneck \& Adey 1976) or L. kotschyanum (Basso et al. 2014).

Our understanding of geniculate (Gabrielson et al. 2011; Hind et al. 2014a, b, 2015) and nongeniculate (Peña et al. 2014, 2015a, b; Sissini et al. 2014; Adey et al. 2015; Hernandez-Kantun et al. 2015; van der Merwe et al. 2015) coralline algal diversity has been significantly revised by the DNA sequencing of types and recent collections and complemented by morphoanatomical studies. In each of these studies the conclusion is clear: most of the historical morphoanatomical features traditionally used to identify species of coralline algae are not reliable enough to be used for identification purposes. In all of these studies, traditional morphoanatomical characters failed to indicate the full depth of species diversity present, although some species in a local region could be correctly identified. Once DNA sequences from field-collected specimens have been linked to type material and morphoanatomical characters have been assessed for sequenced material, only then can a full array of diagnostic characters and methods of analysis useful for field and laboratory identification be revealed. This approach, however, is still in its early days and, for any given local flora, we do not yet know whether morphoanatomical features alone will be adequate to segregate all coralline species.

We tested the synonymies proposed by Tamega et al. (2014) and extended the findings of Basso et al. (2015) by: (1) sequencing a portion of the $r b c \mathrm{~L}$ gene from type specimens of L. kaiseri, L. congestum, L. daedaleum and L. platyphyllum; (2) sequencing 'topotype' specimens of L. stictaeforme from the Mediterranean Sea (Italy and Greece); and (3) sequencing field-collected material assigned to Lithophyllum from the Caribbean Sea, but also from the Gulf of Aqaba, Gulf of Suez, Indian Ocean (Madagascar) and western Pacific Ocean, Great Barrier Reef (GBR) Australia.

\section{MATERIAL AND METHODS}

All field samples were collected by hand or using hammer and chisel while exposed in the intertidal zone or when snorkelling or scuba diving in the subtidal zone (Table S1). DNA was successfully obtained and amplified from 38 specimens from six herbaria (NCU, NY, PC, TRH, TSB and US; see Table S1); herbarium acronyms follow Thiers (2015 continuously updated).

For genetic analyses, selected portions of the plastidencoded $r b c \mathrm{~L}$ and $p s b \mathrm{~A}$ genes were polymerase chain reaction (PCR) amplified and sequenced. DNA extractions, amplifications and sequencing for US and TRH specimens $(r b c \mathrm{~L}$ and $p s b \mathrm{~A})$ followed Adey et al. (2015); for PC specimens ( $p s b \mathrm{~A})$ followed Hernandez-Kantun et al. (2015) and Peña et al. (2015a); for TSB specimens ( $p s b \mathrm{~A})$ followed Hernandez-Kantun et al. (2015); and for NCU specimens ( $p s b \mathrm{~A}$ and $r b c \mathrm{~L}$ ) followed Adey et al. (2015). We also amplified for US specimens a short fragment [600 base pairs (bp)] of psbA using primers reported in Yoon et al. (2002), but following the same protocol that was used for the longer sequence (Adey et al. 2015).

For type material from NY, DNA was extracted using the DNeasy Blood \& Tissue Kit (Qiagen, Valencia, California, USA) following the precautionary guidelines proposed by Hughey \& Gabrielson (2012). Corallines were first ground with a mortar and pestle in a solution containing $270 \mu \mathrm{l}$ of ATL solution and $30 \mu \mathrm{l}$ of proteinase $\mathrm{K}$ supplied with the kit, and 0.5 M EDTA (Sigma-Aldrich, St. Louis, Missouri, USA). The resulting mixture was pipetted into a $1.5-\mathrm{ml}$ microcentrifuge tube and incubated at $56^{\circ} \mathrm{C}$ for $2-3 \mathrm{~h}$ with manual flicking of the tubes every $30 \mathrm{~min}$. The sample was then centrifuged for 1 min at 14,000 revolutions per minute and $200 \mu \mathrm{l}$ of the supernatant was transferred to a new tube containing $200 \mu \mathrm{l}$ of AL solution and $200 \mu \mathrm{l}$ of $95 \%$ ethanol (Sigma-Aldrich). The remaining steps followed the procedures in the kit, with the exception of the elution step. The DNA was eluted a single time with $50 \mu \mathrm{l}$ of buffer AE. For all PCR reactions $6 \mu \mathrm{l}$ of DNA served as template for $50-\mu 1$ reactions following the protocol outlined in the TopTaqTM PCR Handbook, using $10 \mu$ of $5 \times$ Q-Solution (Qiagen). The 1150 cor forward primer (Sissini et al. 2014) was paired with the reverse primer 1460cor (5' GCTGTAGGAGTTTCTA CAAAGTC $3^{\prime}$ ) or with the reverse $r b c S$ (Freshwater \& Rueness 1994) using 1.5 $\mu \mathrm{M}$ concentrations of each primer. Reactions were run on a Perkin Elmer Cetus DNA thermal cycler (Waltham, Massachusetts, USA) with the following parameters: $94^{\circ} \mathrm{C}$ for $90 \mathrm{~s}$, followed by 40 cycles of $94^{\circ} \mathrm{C}$ for $25 \mathrm{~s}, 48^{\circ} \mathrm{C}$ for $30 \mathrm{~s}$, and $72^{\circ} \mathrm{C}$ for $60 \mathrm{~s}$ and final extension of $72^{\circ} \mathrm{C}$ for $5 \mathrm{~min}$. PCR products were purified using the QIAquick PCR purification kit following the manufacturer's instructions (Qiagen). Samples were sequenced using both forward and reverse primers by Functional Biosciences, Inc. (Madison, Wisconsin, USA) and the sequences were edited using Chromas Lite Version 2.01 (Technelysium Pty Ltd, Queensland, Australia).

DNA sequence analyses were performed on two data sets. The first contained variable-length $r b c \mathrm{~L}$ sequences from the isolectotype of Lithophyllum kaiseri, the holotype collection of L. congestum, the holotype of L. daedaleum, 
the holotype of L. platyphyllum and collections from the Caribbean Sea, Gulf of Suez, Red Sea and sequences available in GenBank as L. hibernicum Foslie, L. bathyporum Athanasiadis \& D.L.Ballantine, L. dentatum (Kützing) Foslie, L. incrustans, L. byssoides (Lamarck) Foslie, L. cf. racemus (Lamarck) Foslie, L. orbiculatum (Foslie) Foslie, L. impressum Foslie, L. grumosum (Foslie) Foslie and with the outgroup Phymatolithon calcareum (Pallas) W.H.Adey \& D.L.McKibbin. The second data set included short and long psbA sequences of specimens already identified by $r b c \mathrm{~L}$ sequences and additional material with only $p s b \mathrm{~A}$ sequences, including $L$. stictaeforme from Italy, GenBank sequences deposited as $L$. kotschyanum, L. bathyporum, L. hibernicum, L. dentatum, L. incrustans, L. cf. racemus, L. byssoides, L. orbiculatum, $L$. yemenense, $L$. socotraense and $P$. calcareum and specimens from the Caribbean Sea, GBR Australia and southern Madagascar (Table S1). Both data sets were aligned with ClustalW in Mega version 5 (Tamura et al. 2011) using default settings and refined by eye.

Phylogenetic reconstructions for both data sets were performed using maximum likelihood (ML) in RAxML 1.3 (Mac version, Silvestro \& Michalak 2012). The two data sets were partitioned by codon position using the GTR model with invariant sites and gamma distribution for each of the partitions; statistical support for each of the two sets was obtained from bootstrap (BP) analyses with 1000 resamplings. MrBayes v. 3.2.2 (Huelsenbeck \& Ronquist 2001) was run for Bayesian inference (BI) with the model GTR $+\mathrm{G}+\mathrm{I}$ for each of the partitions. Four Monte Carlo-Markov chains were run for 4 million generations, tree sampling was done every 1000 generations and the stationary distribution of the runs was verified with Tracer v.1.5 (Rambaut \& Drummond 2007); 1000 trees were discarded as burn-in for the $50 \%$ majority-rule consensus trees.

Specimens collected from the Caribbean Sea and housed in US were examined morphoanatomically. Lacking DNA sequences from type material of $L$. stictaeforme and $L$. kotschyanum, we used the most recent detailed morphoanatomical data from type material as reported in Athanasiadis (1999) and Basso et al. (2014, 2015), respectively. Twentythree morphoanatomical features were analysed, including those considered informative/diagnostic in Basso et al. (2014, 2015) and Hernandez-Kantun et al. (2015). Scanning electron microsopical (SEM) procedure and histological preparation of samples for optical microscopy followed Adey et al. (2015) and Steneck \& Adey (1976), respectively. Measurements of vegetative and reproductive features and terminology followed Adey \& Adey (1973).

\section{RESULTS}

Four branched Lithophyllum species are present in the Caribbean Sea on the basis of ML analyses of $r b c \mathrm{~L}$ and psbA sequences (Figs 1, 2). The 263-bp rbcL sequence obtained from an isolectotype of L. kaiseri (NY 00945463) was identical to both holotype collections of L. congestum (TRH A23-1381) preserved in TRH and US, and $L$. daedaleum (NY 00945458) (Fig. 1). These short rbcL sequences were identical over the same length to 1384-bp $r b c \mathrm{~L}$ sequences from field-collected specimens (Table S1) from the Gulf of Aqaba (Nabq, Egypt) and the Caribbean Sea (Cuba, Jamaica and St. Croix). Therefore, both $L$. congestum and L. daedaleum are heterotypic synonyms of the earlier, validly published Lithophyllum kaiseri (Article 11 of the International Code of Nomenclature, McNeill et al. 2012).

The 263-bp $r b c \mathrm{~L}$ sequence from the holotype of the Caribbean Lithophyllum platyphyllum (TRH A23-1401), currently considered a synonym of $L$. congestum, matched sequences from other Caribbean Sea specimens from St. Croix, and differed from L. kaiseri by $11.9-13.8 \%$ for $r b c \mathrm{~L}$ (Fig. 1, Table S2). Closely aligned to this clade were the $r b c \mathrm{~L}$ sequences from other branched, epilithic Caribbean Lithophyllum specimens belonging to two other species named herein as L. neocongestum sp. nov. and L. pseudoplatyphyllum sp. nov. (Table S2, Fig. 1). These latter two species differed from each other by $4.7 \%$ and from L kaiseri by $12.6-15.5 \%$ and 14-15.5\%, respectively. Lithophyllum pseudoplatyphyllum sp. nov. differed from L. platyphyllum by $1.7-2.2 \%$. in $p s b \mathrm{~A}$ and $1.9 \%$ in $r b c \mathrm{~L}$.

The $p s b \mathrm{~A}$ sequences obtained from the same fieldcollected specimens from which $r b c \mathrm{~L}$ sequences had been obtained aligned with the type material of Lithophyllum kaiseri, L. platyphyllum, L. neocongestum and L. pseudoplatyphyllum. The psbA sequences analysed from other representative unbranched and branched Lithophyllum species worldwide confirmed the presence of four species in the Caribbean Sea (Fig. 2). Three of these species (L. platyphyllum, L. neocongestum, L. pseudoplatyphyllum) have localized distributions, whereas L. kaiseri is confirmed from the Caribbean Sea, Red Sea (Gulf of Suez and Gulf of Aqaba) and the Indo-West Pacific (Australia: One Tree Island; Madagascar: Toliara Province; Japan: Okinawa, GenBank AB576031, as L. kotschyanum). The psbA sequences from specimens shown to be $L$. kaiseri had $\mathrm{p}$ distance values ranging from 0 to $0.7 \%$, indicating that they represented a single species distributed in the western Indo-Pacific and Red Sea with a disjunct population in the Caribbean Sea (Table S2). These specimens, along with the tropical, branched Lithophyllum species recently reported in Basso et al. (2015), occurred in two clades, one with strong support $(98 \% / 0.98)$ containing L. kaiseri, L. socotraense and an unnamed species from Vanuatu, and the other clade with moderate to strong support $(83 \% / 0.99)$ containing L. neocongestum, L. platyphyllum, L. pseudoplatyphyllum, L. yemenense, GenBank sequences from the Western Pacific identified as $L$. kotschyanum (AB576030 and AB576029) and four unidentified specimens. An unresolved relationship is observed for these two clades with New Zealand species (72\%/1) and European Lithophyllum species (98\%/1). The psbA sequences for L. stictaeforme from the Mediterranean (Italy and Greece) were not related to the clade containing L. kaiseri (Fig. 2).

States of 23 morphoanatomical characters (Table 1) that had been previously used to segregate Lithophyllum species (Athanasiadis 1999; Basso et al. 2014, 2015; HernandezKantun et al. 2015) were assessed. Lithophyllum stictaeforme was the most distinctive species, differing from all others by its habit, lamellate morphology of encrusting thalli, absence 


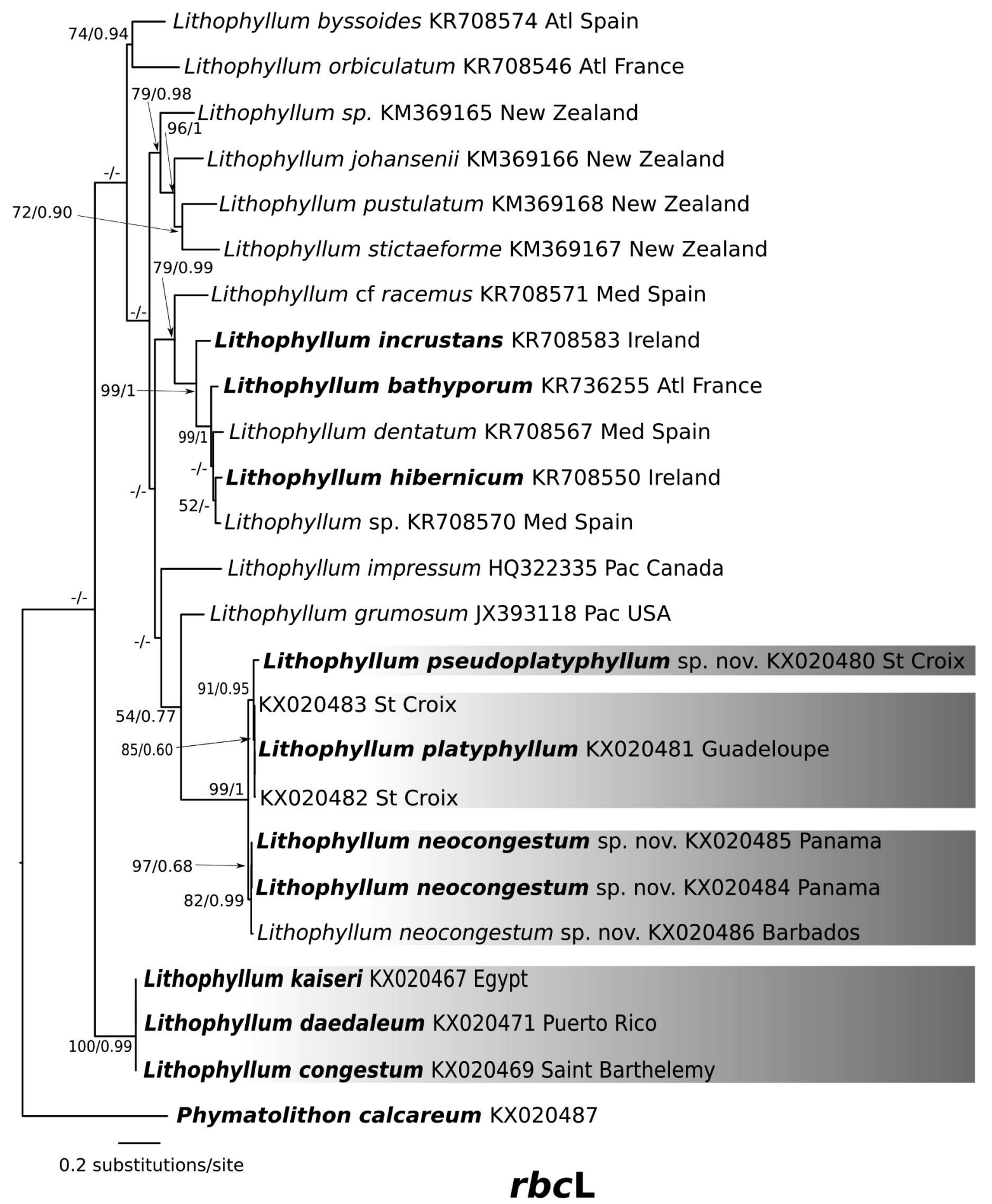

Fig. 1. ML phylogeny based on $r b c \mathrm{~L}$ sequences for Lithophyllum spp. Species with sequenced type material marked in bold. Specimen numbers and country/island of collection provided. Branch nodes have BP for ML analysis and posterior probability (PP) for BI analysis (e.g. 96/0.99). Support values below 50\% for BP and 0.7 for PP marked as (-); other identical sequences listed for each taxon in Table S1.

Fig. 2. ML phylogeny based on $p s b \mathrm{~A}$ sequences for Lithophyllum spp. Species with sequenced type material or complementary $r b c \mathrm{~L}$ sequences matching type material marked in bold. Specimen numbers and country/island of collection provided. Branch nodes have BP for ML analysis and posterior probability (PP) for BI analysis (e.g. 96/0.99); (*) denotes clades fully supported in both reconstructions (100\% BP/1.0 PP). Support values below $50 \%$ for BP and 0.7 for PP marked as (-). Other identical sequences listed in Table S1. 


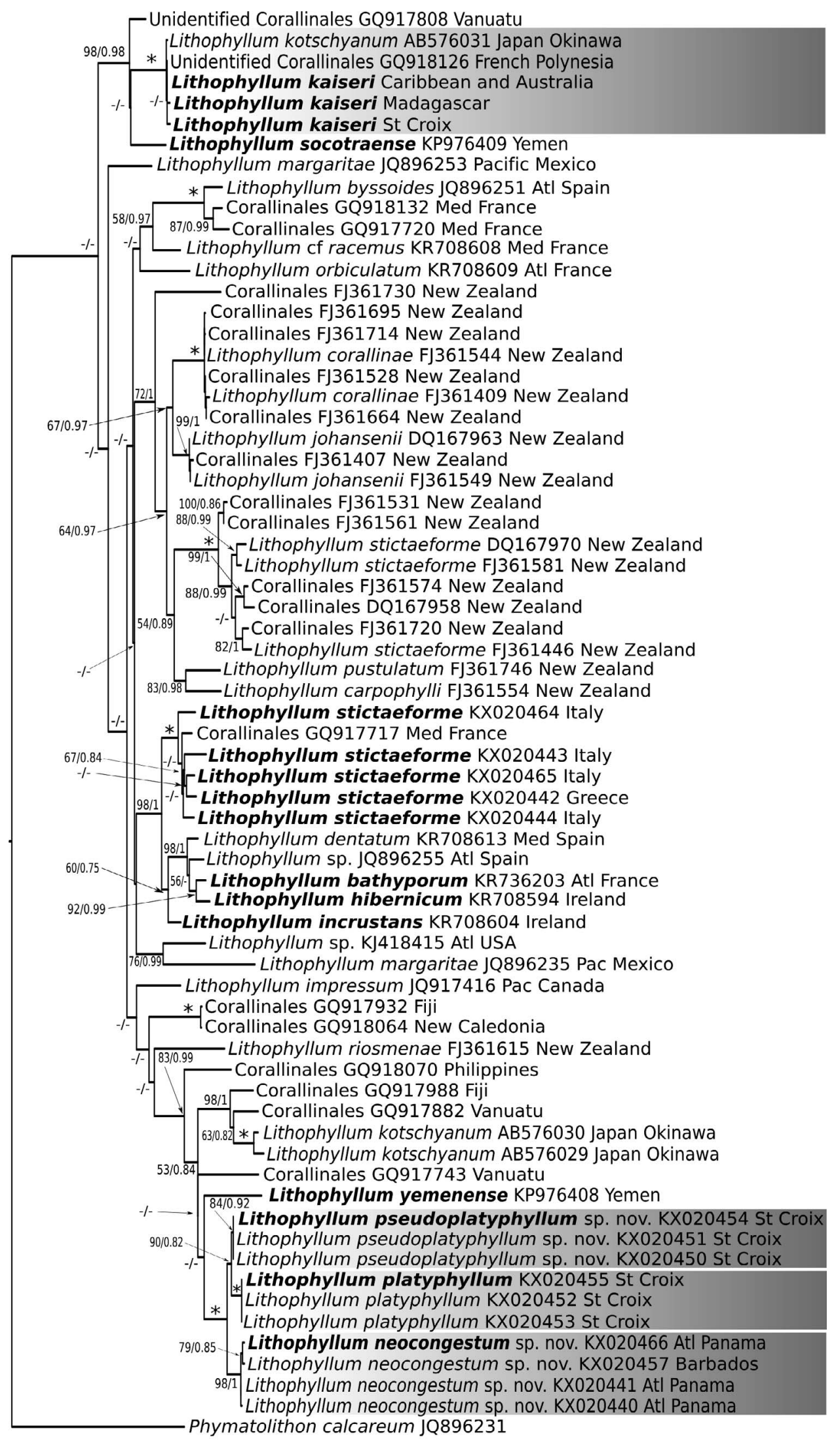


Table 1. Comparison of vegetative and reproductive features of Lithophyllum kaiseri, L. kotschyanum, L. stictaeforme and the two new species L. pseudoplatiphyllum and L. neocongestum. Bold font indicates differences of the character state from L. kaiseri. Standard deviation in parentheses from Basso et al. (2014). $\mathrm{ND}=$ no data; $\mathrm{P}=$ present; $\mathrm{A}=$ absent; $\mathrm{NG}=$ nongeniculate; $\mathrm{F}=$ fruticose; $\mathrm{S}=$ foliose; $\mathrm{CB}=$ columnar branched; $\mathrm{FB}=$ foliose branched; $\mathrm{T}=$ tapering; $\mathrm{M}=$ mucilaginous. Table is adapted from Athanasiadis (1999), Basso et al. (2015) and Hernandez-Kantun et al. (2015).

\begin{tabular}{|c|c|c|c|c|c|c|}
\hline & $\begin{array}{l}\text { L. }_{(n a i s e r i}{ }^{1} \\
(n=16)\end{array}$ & $\begin{array}{l}\text { L. kotschyanum }{ }^{2} \\
(n=1)\end{array}$ & $\begin{array}{l}\text { L. stictaeforme }{ }^{3} \\
(n=1)\end{array}$ & $\begin{array}{l}\text { L. platyphyllum } \\
(n=4)\end{array}$ & $\begin{array}{l}\text { L. pseudoplatiphyllum } \\
(n=3)\end{array}$ & $\begin{array}{l}\text { L. neocongestum } \\
\quad(n=3)\end{array}$ \\
\hline \multicolumn{7}{|l|}{ Vegetative features } \\
\hline Habit/growth form & $\mathrm{NG} / \mathrm{F}-\mathrm{CB}, \mathrm{FB}$ & $\mathrm{NG} / \mathrm{F}$ & NG/S & $\mathrm{NG} / \mathrm{F}-\mathrm{CB}, \mathrm{FB}$ & $\mathrm{NG} / \mathrm{F}-\mathrm{CB}, \mathrm{FB}$ & $\mathrm{NG} / \mathrm{F}-\mathrm{CB}$ \\
\hline Epithallial cell length $(\mu \mathrm{m})$ & $2-7$ & 2.5 & ND & $3-6$ & $3-7$ & $3-4$ \\
\hline Epithallial cell width $(\mu \mathrm{m})$ & $5-14$ & $11(1.4)$ & ND & $6-9$ & $6-10$ & $4-8$ \\
\hline $\begin{array}{l}\text { Perithallium cell length } \\
(\mu \mathrm{m})\end{array}$ & $16-22$ & $19.4(7.5)$ & $10-24$ & $20-25$ & $12-25$ & $5-6$ \\
\hline $\begin{array}{l}\text { Perithallium cell width } \\
(\mu \mathrm{m})\end{array}$ & $6-9$ & $8.9(1.1)$ & $12-17$ & $8-10$ & $6-12$ & 4-6 \\
\hline Meristem cell length $(\mu \mathrm{m})$ & $5-17$ & ND & $6-14$ & $6-10$ & $6-10$ & $6-15$ \\
\hline Meristem cell width $(\mu \mathrm{m})$ & $5-18$ & ND & $12-14$ & $8-15$ & $6-18$ & $6-10$ \\
\hline Number of epithallial cells & $1-2$ & 1 & 1 & 1 & 1 & 1 \\
\hline Trichocytes & $\mathrm{P}$ & $\mathrm{P}$ & $\mathbf{A}$ & $\mathrm{P}$ & $\mathrm{P}$ & $\mathrm{P}$ \\
\hline \multicolumn{7}{|l|}{ Reproductive features } \\
\hline $\begin{array}{l}\text { Number of cells forming } \\
\text { the roof }\end{array}$ & $4-6$ & 7 & $5-10$ & $4-7$ & $5-7$ & $4-5$ \\
\hline $\begin{array}{l}\text { Rim at the bottom of the } \\
\text { pore canal }\end{array}$ & A & A & $\mathbf{P}$ & A & A & A \\
\hline $\begin{array}{l}\text { Rim at the surface of the } \\
\text { pore canal }\end{array}$ & A & A & ND & A & A & A \\
\hline Shape of the pore canal ${ }^{4}$ & $\mathrm{~T}$ & $\mathrm{~T}$ & $\mathrm{~T}$ & $\mathrm{~T}$ & $\mathrm{~T}$ & $\mathrm{~T}$ \\
\hline $\begin{array}{l}\text { Depth of the conceptacle } \\
\text { chamber floor (\# of } \\
\text { cells) } \\
\text { Columella presence/ }\end{array}$ & $10-14$ & 16-17 & $14-15$ & $7-10$ & $13-14$ & $7-10$ \\
\hline$a^{a b s e n c e}{ }^{4}$ & $\mathrm{P}$ & $P$ & $\mathrm{P}$ & $P$ & $P$ & $P$ \\
\hline Columella \# of cells high ${ }^{4}$ & 2 & 5 & 4 & 2 & $2-3$ & $2-3$ \\
\hline $\begin{array}{l}\text { Roof of conceptacle with } \\
\text { reference of the } \\
\text { epithallial layer } \\
\text { Concentacle chamber }\end{array}$ & raised & raised & flush & raised & raised & raised \\
\hline $\begin{array}{l}\text { Conceptacle chamber } \\
\text { diameter }(\mu \mathrm{m})^{4} \\
\text { Concentacle chamber }\end{array}$ & $90-325$ & $310-380$ & $375-475$ & $200-275$ & $125-200$ & $230-275$ \\
\hline $\begin{array}{l}\text { Conceptacle chamber } \\
\text { height }(\mu \mathrm{m})^{4}\end{array}$ & $75-125$ & 131 (18.6) & $100-175$ & $65-130$ & $70-80$ & $75-80$ \\
\hline $\begin{array}{l}\text { Nature of spores in bi/ } \\
\text { tetrasporangia } \\
\text { Tetra/bisporangia length }\end{array}$ & $\begin{array}{l}\text { tetra and bi } \\
\text { tetra }=50-58\end{array}$ & tetra* & ND & tetra & tetra & tetra \\
\hline $\begin{array}{l}(\mu \mathrm{m}) \\
\text { Tetra/bisporangia width }\end{array}$ & $\begin{array}{l}\mathrm{bi}=38-78 \\
\text { tetra }=38-40\end{array}$ & ND & ND & $60-70$ & $50-80$ & $50-70$ \\
\hline $\begin{array}{l}(\mu \mathrm{m}) \\
\text { Concentacles buried }\end{array}$ & $\mathrm{bi}=17-21$ & ND & ND & $25-30$ & $18-25$ & $20-30$ \\
\hline $\begin{array}{l}\text { Conceptacles buried } \\
\text { within thallus }\end{array}$ & $\mathrm{P}$ & ND & $P$ & $P$ & $\mathrm{P}$ & $\mathrm{P}$ \\
\hline
\end{tabular}

* Data require confirmation.

${ }^{1}$ Data obtained herein using the isolectotype of L. kaiseri and DNA matching specimens in US.

${ }^{2}$ Data obtained from the holotype of L. kotschyanum analysed by Basso et al. (2014). Measurements are means \pm standard deviation.

${ }^{3}$ Data obtained from the holotype of L. stictaeforme analysed by Athanasiadis (1999). The same author identified the presence of a rim at the bottom of the pore canal, which in this case is a diagnostic feature contrasting with the rest of the species herein analysed.

${ }^{4}$ For L. kaiseri these measurements include bisporangial and tetrasporangial conceptacles.

of trichocytes, presence of a rim at the base of each pore canal of tetra/bisporangial conceptacle and tetra/bisporangial conceptacle roofs that are flush with the thallus surface (Athanasiadis 1999). Cell size was generally uninformative, except for the small perithallial cells of $L$. neocongestum that were distinctive (Table 1). Four tetra/bisporangial conceptacle characters distinguished some species, including the number of cells in the conceptacle roof, the depth (in number of cells) of conceptacle chamber floor, and the height and diameter of the conceptacle chambers. The remaining characters could not be used to distinguish among the species.
Using the $p s b \mathrm{~A}$ and $r b c \mathrm{~L}$ sequence data as well as morphoanatomical characters, we emended here the descriptions of Lithophyllum kaiseri and L. platyphyllum, and formally describe $L$. neocongestum and L. pseudoplatyphyllum.

\section{Lithophyllum kaiseri (Heydrich) Heydrich, 1897a: 412}

(Figs 3-17, S1-S4)

BASIONYM: Lithothamnion kaiseri Heydrich, 1897b: 64, pl. III, figs 8, 12,13 . 

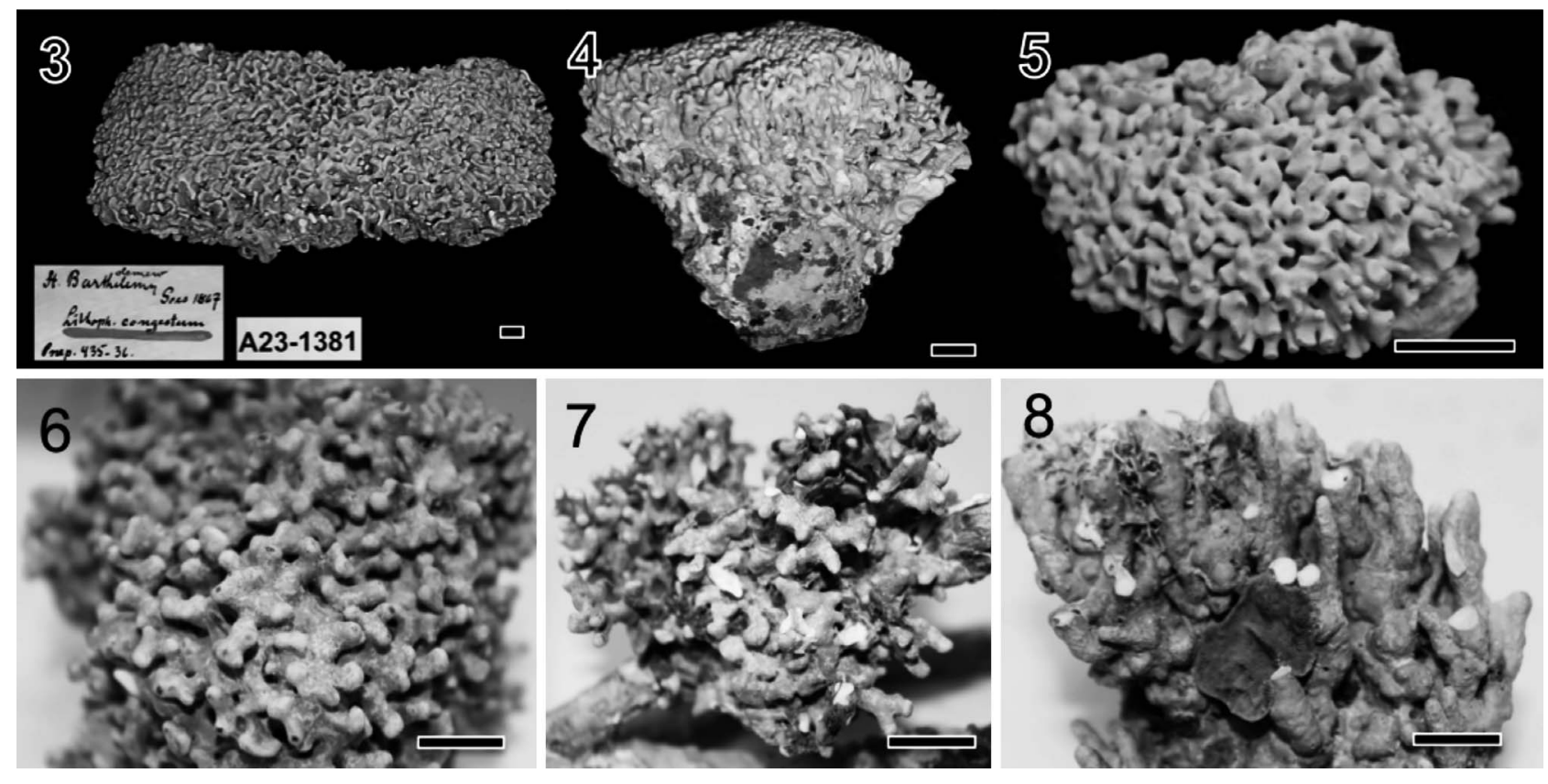

Figs 3-8. Gross morphology of Caribbean Sea Lithophyllum kaiseri. Scale bars $=1 \mathrm{~cm}$.

Fig. 3. Specimen from holotype collection of Lithophyllum congestum (TRH A23-1381) (S15).

Fig. 4. Specimen from holotype of Lithophyllum congestum (TRH A23-1381 in US) (S8).

Fig. 5. Specimen from holotype collection of Lithophyllum congestum (TRH A23-1381) (S13).

Fig. 6. Specimen US 170945 (S38), St. Croix.

Fig. 7. Specimen US 170945 (S61), St. Croix.

Fig. 8. Specimen US 169411 (S51), St. Croix.

LECTOTYPE: TRH A20-1264; Dr A. Kaiser, on corals; collection date unknown; leg. A. Kaiser; only the small specimen in the box of the syntype collection of Heydrich no. 60, including slide 6, was designated as lectotype of Lithphyllum kaiseri by Basso et al. (2015, fig. 4).

ISOLECTOTYPE: NY 00945463; exclusively the largest specimen in the box is designated here as an isolectotype of Lithophyllum kaiseri.

TYPE LOCALITY: El Tor, Sinai Peninsula, Egypt (Basso et al. 2015: 188).

HETEROTYPIC SYNONYMS: Goniolithon congestum Foslie, 1899: 13; Lithophyllum congestum (Foslie) Foslie, 1900: 20; Lithophyllum daedaleum Foslie \& M.Howe, 1906: 133.

ETYMOLOGY: The epithet kaiseri is dedicated to Dr. A. Kaiser, who collected the type specimens (Heydrich 1897b; Basso et al. 2015).

DNA SEQUENCES: The $r b c \mathrm{~L}$ sequences were obtained from: the isolectotype of Lithophyllum. kaiseri (NY 00945463; 263 bp, GenBank KX020467); three specimens from the holotype collection of L. congestum (TRH A23-1381 and TRH A23-1381 in US; 271 bp, GenBank KX020468, KX020469, KX020470); the holotype of L. daedaleum (NY 00945458; 309 bp, GenBank KX020471). All of these sequences were identical over the entire overlapping 263-bp length.

Field-collected specimens were from the US Virgin Islands, Jamaica, Cuba, Martinique, Australia, Egypt and Madagascar. Only five of 15 specimens yielded both markers $(r b c \mathrm{~L}$ and $p s b \mathrm{~A})$. The $r b c \mathrm{~L}$ sequences varied in length from
160 to $1387 \mathrm{bp}$ from eight field-collected specimens and were identical to the Lithophyllum kaiseri isolectotype sequence. Similarly, psbA sequences from nine specimens varied in length from 292 to $851 \mathrm{bp}$ and also were identical to $L$. kaiseri. A 1-bp difference from the L. kaiseri isolectotype was observed for the $p s b \mathrm{~A}$ gene for three sequences from the US Virgin Islands (GenBank KX020446, KX020448, KX020449).

HABITAT AND HABIT: The species occurred on exposed reef crests to 3-m depth. Thalli had a fruticose, branched habit with some anastomosed branches. Branches columnar and foliose. No morphological differences were encountered among specimens collected at widely separated sites (Figs 3-8). Colour of living thalli in the field ranged from pink to purple. Epiphytes and endophytes were observed in specimens from the Caribbean Sea (Figs S1-S4).

vegetative ANATOMY: Thallus monomerous and dimerous with noncoaxial hypothallium (Fig. 9). Hypothallial cells measured 13-25 $\times$ 4-7 $\mu \mathrm{m}$ [length $\times$ width $(\mathrm{L} \times \mathrm{W})]$. The perithallium comprised elongate cells that measured 16-22 $\times$ 6-9 $\mu \mathrm{m}(\mathrm{L} \times \mathrm{W})$ (Fig. 10). Primary and secondary pit connections (Fig. 11) were readily visible in transverse fractures. Square to elongate meristematic cells measured 5-17 $\times 5-18 \mu \mathrm{m}(\mathrm{L} \times \mathrm{W})($ Fig. 11). In transverse fracture, rectangular-shaped epithallial cells occurred in one to two layers and measured 2-7 $\times 5-14 \mu \mathrm{m}(\mathrm{L} \times \mathrm{W})($ Fig. 12). In surface view epithallial cells were flat or in some cases had 

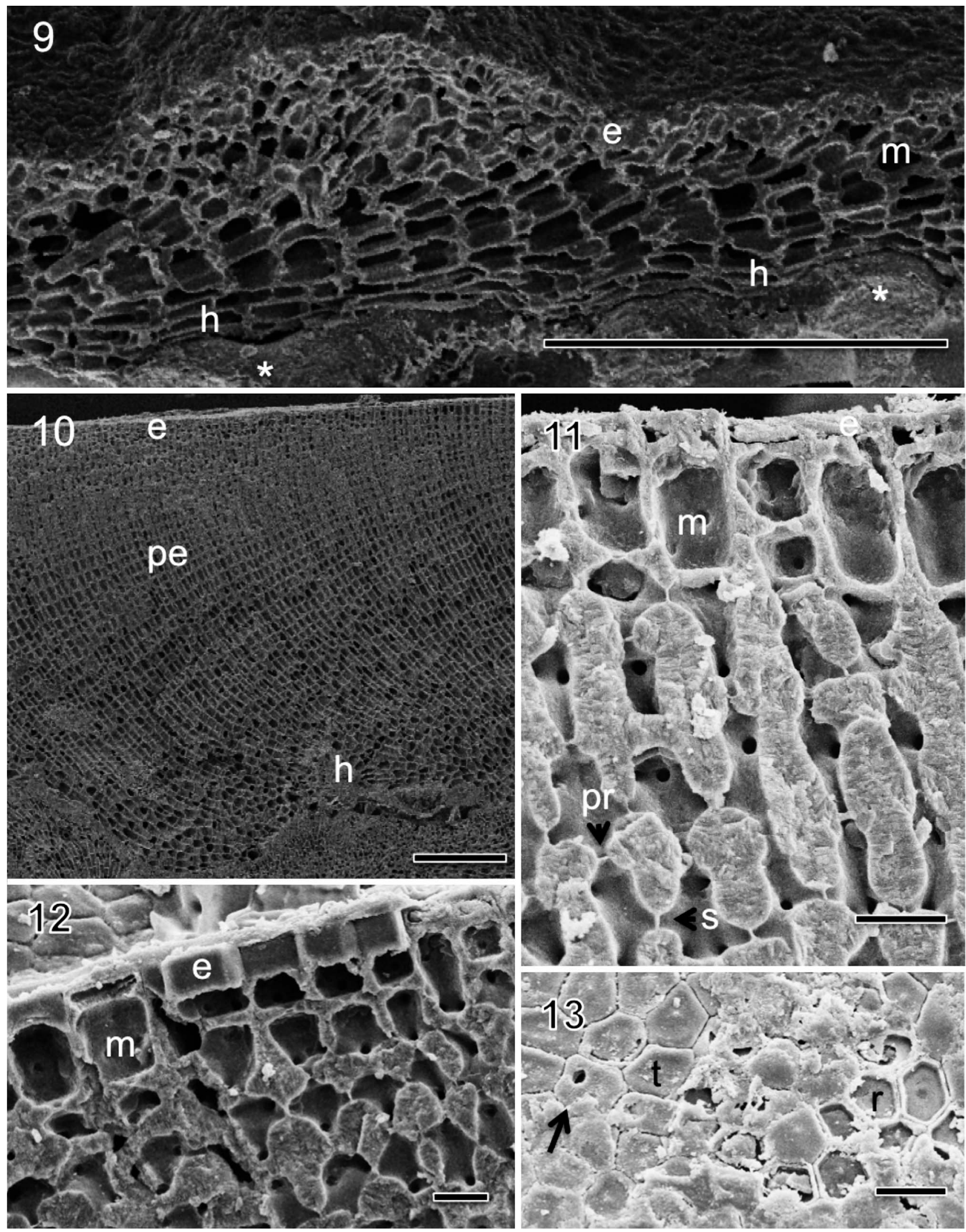

Figs 9-13. Lithophyllum kaiseri vegetative anatomy using SEM (Caribbean Sea specimens).

Fig. 9. Transverse fracture of young thallus showing monomerous hypothallus (h) growing on substratum $\left(^{*}\right)$; meristem $(\mathrm{m})$ and epithallium (e) visible. US 170945 (S38). Scale bar $=100 \mu \mathrm{m}$. 
rim-like tops (Fig. 13), and solitary trichocytes were visible by their pores (Fig. 13).

REPRODUCTIVE ANATOMY: No gametangial conceptacles were observed. Tetra/bisporangial conceptacles were raised and their chambers measured 75-125 × 90-325 $\mu \mathrm{m}(\mathrm{L} \times \mathrm{W})$ (bisporangial conceptacle Figs 14, S5). Conceptacle roofs were comprised of four to six cells (Fig. 14), the pore canal was tapered (Fig. 14) and the base of the pore canal lacked a rim. The pore canal were often occluded by a mucilaginous plug (Fig. 15). The conceptacle chamber floor was 10-14 cells below the surrounding thallus surface and had a central columella (Fig. 14) formed by pre-existing perithallial filaments two cells thick. Tetrasporangia were $50-58 \times 38-$ $40 \mu \mathrm{m}(\mathrm{L} \times \mathrm{W})$. Bisporangia were $38-78 \times 17-21 \mu \mathrm{m}(\mathrm{L} \times$ W). (Figs 16, 17; Table 1).

DISTRIBUTION: On the basis of DNA sequences the species occurred in Egypt, Madagascar (Toliara Province), Japan (Okinawa), GBR Australia, Jamaica, Cuba, Martinique and the US Virgin Islands.

COMMENT: The isolectotype collection of Lithophyllum kaiseri in NY comprised four specimens and six slides in a box with a label in Howe's hand, 'type or type duplicate'. The label inside the box read 'Ex Museo botanico Berolinensi. Lithophyllum kaiserii Heydrich, El Tor, Rotes Meer, viii.1897, leg. Kaiser, Sammlung [collection] Heydrich' (photos of type here: http://sweetgum.nybg.org/science/vh/specimen_details. php?irn=1017821). The $r b c \mathrm{~L}$ sequence was obtained from the largest specimen in the collection. The holotype collection of L. congestum (TRH A23-1381) contained five specimens, two slides and many small fragments. Fragments were taken from four of the five specimens with $r b c \mathrm{~L}$ sequences obtained from two (Figs 3,5$)$ as well as from specimen TRH A23-1381 in US (Fig. 4). The holotype collection of L. daedaleum comprised three individuals; the $r b c \mathrm{~L}$ sequence was obtained from the largest (Foslie \& Howe 1906, pl. 83, bottom; see also: http://sweetgum. nybg.org/vh/specimen.php?irn=1012949).

\section{Lithophyllum platyphyllum (Foslie) Foslie, 1900: 18} (Figs 18-24)

BASIONYM: Goniolithon platyphyllum (Foslie) Foslie, 1899, p. 13

HOLOTYPE: TRH A23-1401; P.T.Cleve; no date; no habitat data on type; leg. P.T.Cleve (Fig. 18).

TYPE LOCALITY: St. Martin, near Guadeloupe, West Indies (French Antilles) (Woelkerling et al. 2005: 192).

ETYMOLOGY: The epithet platyphyllum resulted from two words; platy of Greek origin meaning broad, wide, level, flat; and phyllum of Greek origin meaning leaf (Brown 1956).

DNA SEQUENCES: A 263-bp $r b c \mathrm{~L}$ sequence (GenBank KX020481) from the holotype of Lithophyllum platyphyllum (TRH A23-1401) was obtained. The sequence was identical in its $263 \mathrm{bp}$ to two other sequences (567 and $675 \mathrm{bp}$ in length, GenBank KX020482 and KX020483, respectively) obtained from US Virgin Islands specimens. Three psbA sequences, 399 to 842 bp long (KX020455, KX020452, KX020453), also from the US Virgin Islands specimens, were identical to each other over comparable lengths

HABITAT AND HABIT: This species was found on exposed reef crests to 3-m depth. Thalli were formed by columnar and foliose branches, varying in thickness from 0.1 to $1 \mathrm{~cm}$ (Figs 18-20). Colour of living thalli in the field ranged from purple to dark pink.

VEGETATIVE ANATOMY: Thallus monomerous with noncoaxial hypothallium (Fig. 21). Hypothallial cells measured 12-25 $\times 5-7 \mu \mathrm{m}(\mathrm{L} \times \mathrm{W})($ Fig. 21$)$. Perithallium comprised elongate cells that measured 20-25 $\times 8-10 \mu \mathrm{m}(\mathrm{L} \times \mathrm{W})($ Fig. 21). In transverse fracture primary and secondary pit connections are visible (Fig. 22), whereas trichocytes were rare. Squared to elongated meristematic cells measured 6-10 $\times 8-15 \mu \mathrm{m}(\mathrm{L}$ $\times \mathrm{W}$ ) (Fig. 22). In transverse fractures rectangular-shaped epithallial cells occurred in one layer (Figs 22, 23). Epithallial cells measured 3-6 $\mu \mathrm{m} \times 6-9 \mu \mathrm{m}(\mathrm{L} \times \mathrm{W})($ Figs 22,23$)$. In surface view epithallial cells were flat or in some cases with rim-like edges (Fig. 24).

REPRODUCTIVE ANATOMY: No gametangial conceptacles were observed. Tetrasporangial conceptacles were protruding with chambers measuring 65-130 × 200-275 $\mu \mathrm{m}(\mathrm{L} \times \mathrm{W})$ (Fig. 25). Tetrasporangial conceptacle roofs were comprised of four to seven cells (Fig. 24), the pore canal was tapered (Fig. 25) and the base of the pore canal lacked a rim. The pore canal was often occluded by a mucilaginous plug (Fig. 26). The conceptacle chamber floor was $7-10$ cells below the surrounding thallus surface and comprised a central columella (Fig. 25) formed by pre-existing perithallial filaments two cells thick. See Table 1 for tetrasporangial dimensions (Fig. 26). Buried conceptacles were present.

DISTRIBUTION: French Antilles and the US Virgin Islands.

\section{Lithophyllum neocongestum J.J.Hernandez-Kantun, W.H.Adey \& P.W.Gabrielson, sp nov.}

(Figs 27-35)

DIAGNOSIS: Nongeniculate coralline with fruticose columnar branched thalli. Colour dark pink to purple. Thallus monomerous with noncoaxial hypothallium. Square perithallial cells measured 5-6 $\times 4-6 \mu \mathrm{m}(\mathrm{L} \times \mathrm{W})$. Epithallial cells occurred in one layer; trichocytes, primary and secondary pit connections present. Uniporate tetrasporangial conceptacles were raised and the chambers measured 75-80 $\times$ 230-275 $\mu \mathrm{m}(\mathrm{L} \times \mathrm{W})$. Tetrasporangia were 50-70 $\times 20-30 \mu \mathrm{m}(\mathrm{L} \times$ W). Tetrasporangial chamber roof was formed by four to five cells and was 7-10 cells below the thallus surface.

Fig. 10. Transverse fracture of older thallus showing monomerous hypothallus (h), perithallium (pe) and epithallum (e). US 170945 (S38). Scale bar $=100 \mu \mathrm{m}$.

Fig. 11. Transverse fracture of thallus showing single epithallial cell layer with lost roof (e) and meristematic cell (m). Primary (pr) and secondary (s) pit connections visible. TRH A23-1381 (S15). Scale bar $=10 \mu \mathrm{m}$.

Fig. 12. Transverse fracture of thallus showing single epithallial cell layer with intact cell (e) and meristematic cell (m). US 170945 (S61). Scale bar $=10 \mu \mathrm{m}$.

Fig. 13. Surface view of epithallial cells with intact (t) and lost (r) roofs. Trichocyte opening (arrow) visible. Specimen US 170945 (S38). Scale bar $=10 \mu \mathrm{m}$. 


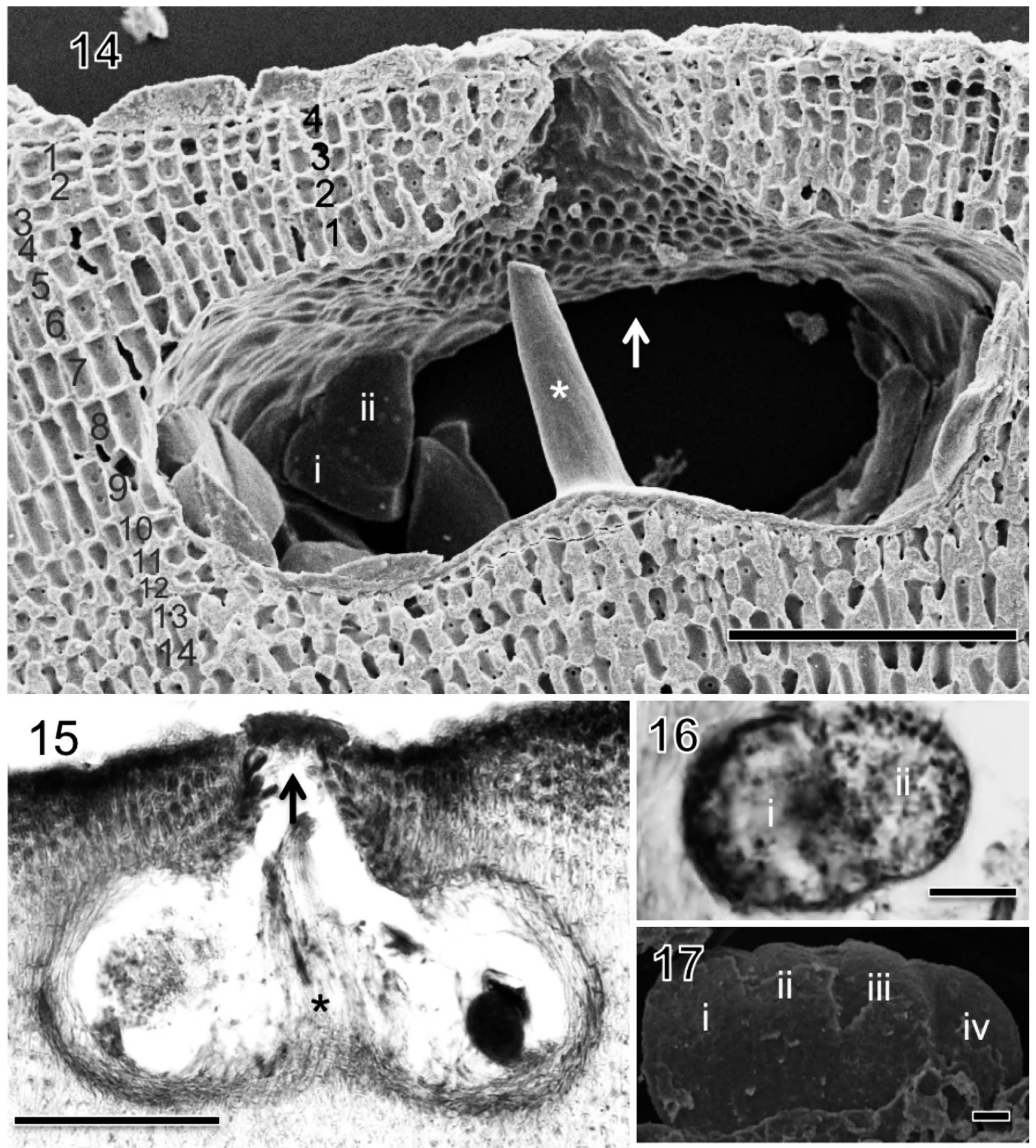

Figs 14-17. Lithophyllum kaiseri tetra/bisporangial conceptacles in transverse fracture; SEM unless specified (Caribbean Sea).

Fig. 14. Transverse fracture of thallus showing bisporangial conceptacle with central columella (asterisk) and roof of four to five cell layers (black numbers). Bisporangial conceptacle occupied 14 cell layers from conceptacle surface to base (grey numbers). Bisporangia (count in Roman numbers) and tapering shape of pore canal (arrow). US 169407. Scale bar $=100 \mu \mathrm{m}$.

Fig. 15. Histological view of bisporangial conceptacle with columella $\left(^{*}\right)$; pore canal blocked by mucilage plug (arrow). US 170947. Scale bar $=100 \mu \mathrm{m}$

Fig. 16. Histological view of bisporangia (count in Roman numbers). US 170947. Scale bar $=25 \mu \mathrm{m}$.

Fig. 17. Transverse fracture of thallus showing detail of tetrasporangia (count in Roman numbers). US 170947 . Scale bar $=10 \mu \mathrm{m}$. 


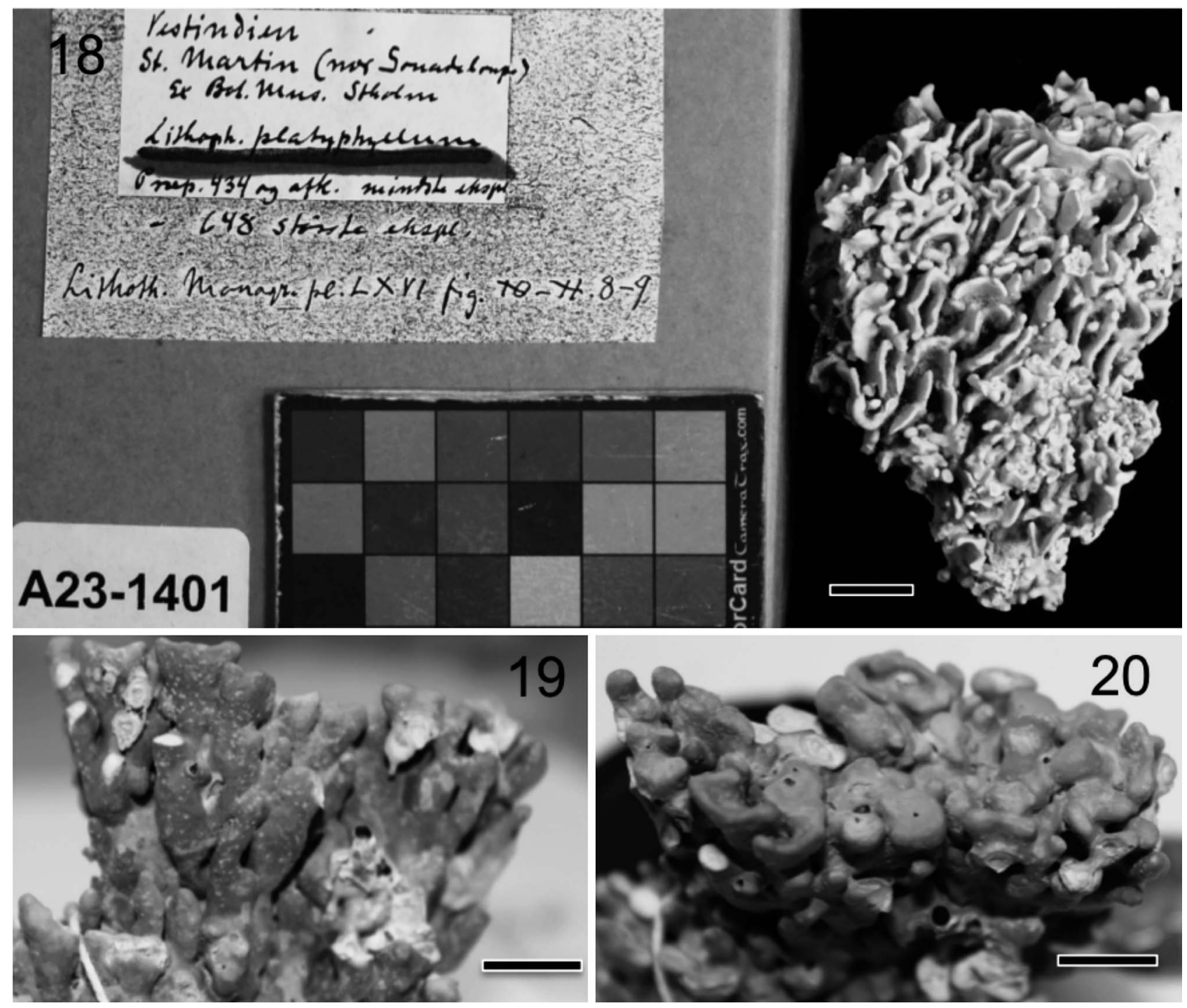

Figs 18-20. Lithophyllum platyphyllum gross morphology (Caribbean Sea). Scale bars $=1 \mathrm{~cm}$.

Fig. 18. Holotype of Lithophyllum platyphyllum, TRH A23-1401.

Fig. 19, 20. Lateral and surface view respectively, of specimen with thick $(0.5$ to $1 \mathrm{~cm})$ column-like branches. US 170946.

HOLOTYPE: US 223011; 6 August 2010; off Shark Hole Point, Peninsula Valiente, Bocas del Toro, Panama; subtidal, 0-1-m depth; leg. B. Wysor (Fig. 27).

ISOTYPE: NCU 598862 (Fig. 28). B. Wysor, 6 August 2010; off Shark Hole Point, Peninsula Valiente, Bocas del Toro, Panama; subtidal, $-0.5 \mathrm{~m}$.

TYPE LOCALITY: Off Shark Hole Point, Peninsula Valiente, Bocas del Toro, Panama.

ETYMOLOGY: The epithet neocongestum is explained by the word neo of Greek origin meaning new; and congestum of Latin origin meaning dense (Brown 1956). The word neo is used in conjunction with the term congestum to denote the close relationship in morphoanatomy of the new species with the former Lithophyllum congestum.

DNA SEQUENCES: From the holotype of Lithophyllum neocongestum sequence (GenBank KX020466). The isotype (NCU 598862) $r b c \mathrm{~L}$ sequence (GenBank KX020485) was identical with the holotype sequence, whereas the sequence
(GenBank KX020486) from another specimen (US 169412) differed by 4 bp from the holotype. Three $p s b \mathrm{~A}$ sequences from 453 to $695 \mathrm{bp}$ in length were obtained: a sequence (GenBank KX020457) from US 169412 differed from the holotype psbA sequence (GenBank KX020466) by 2 bp, whereas specimens US 170968 (GenBank KX020440) and US 170967 (GenBank KX020441) differed from the holotype sequence by $4 \mathrm{bp}$. These sequences were obtained from material from Barbados and Panama (Bocas del Toro), respectively.

HABITAT AND HABIT: The species occurred on exposed reef crests and subtidal to $3 \mathrm{~m}$ depth. Thalli were encrusting smooth to columnar branched habit (Figs 27-29) and dark pink to purple.

VEGETATIVE ANATOMY: Thallus monomerous with noncoaxial hypothallium (Fig. 30). Hypothallial cells measured 6-8 $\times$ 5-6 $\mathrm{m}(\mathrm{L} \times \mathrm{W})$ (Fig. 30). The perithallium comprised 

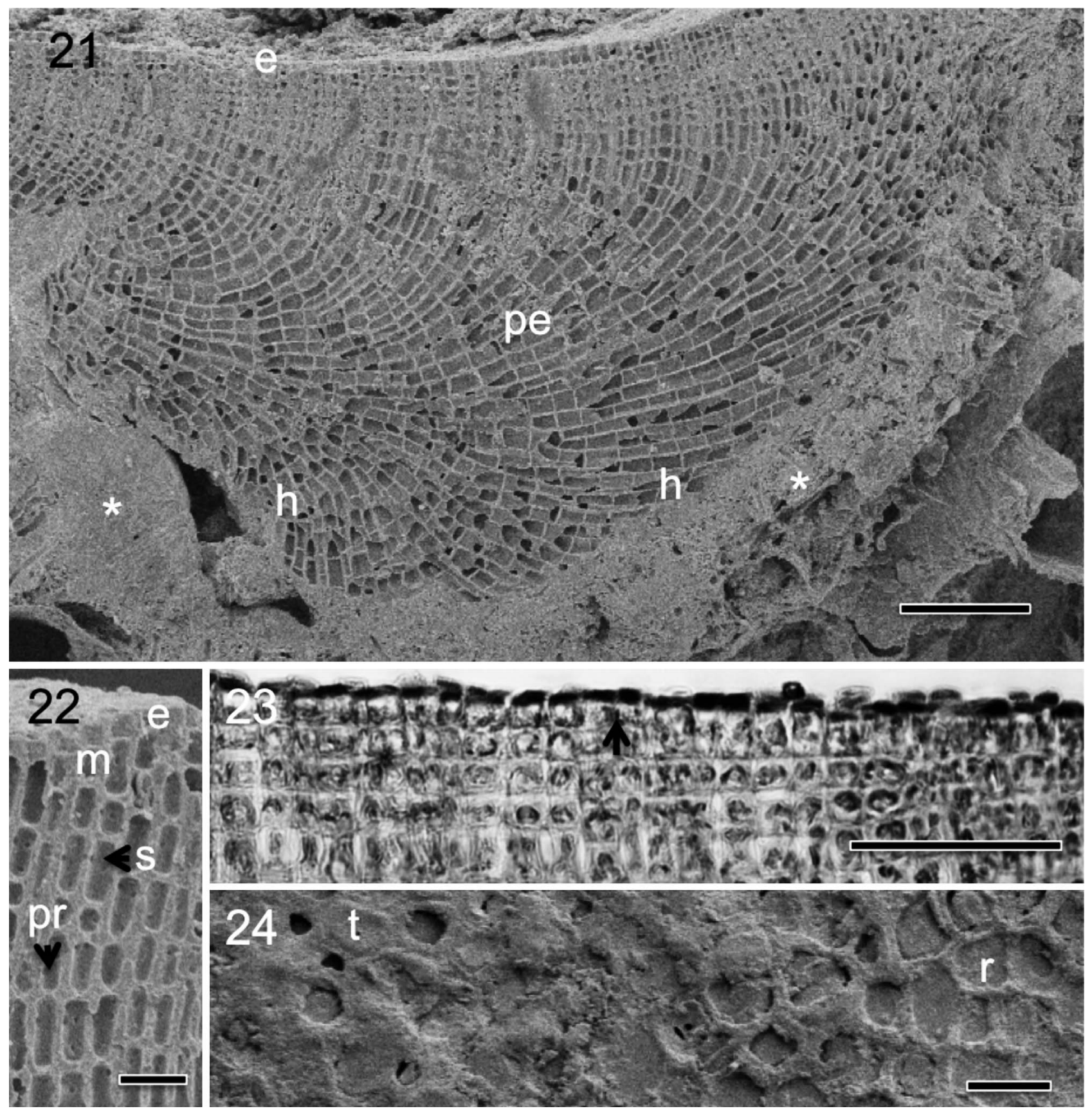

Figs 21-24. Lithophyllum platyphyllum vegetative morphoanatomy (SEM unless specified), US 170946.

Fig. 21. Transverse fracture of thallus showing monomerous hypothallus (h) growing on substratum $(*)$; epithallium (e) and perithallium (pe) visible. Scale bar $=100 \mu \mathrm{m}$.

Fig. 22. Transverse fracture of thallus showing single epithallial cell layer (e) and meristematic cell (m); primary (pr) and secondary (s) pit connection indicated. Scale bar $=20 \mu \mathrm{m}$.

Fig. 23. Histological view of thallus showing one layer of flat elongated epithallial cells (arrow). Scale bar $=50 \mu \mathrm{m}$.

Fig. 24. Transverse fracture of thallus showing surface of epithallial cells with intact (t) and lost (r) roofs. Scale bar $=10 \mu \mathrm{m}$.

square cells that measured 5-6×4-6 $\mu \mathrm{m}(\mathrm{L} \times \mathrm{W})($ Fig. 30). Primary and secondary pit connections visible in transverse fractures (Fig. 31), whereas trichocytes were rare (Fig. 32). Square to elongate meristematic cells measured 6-15 $\times 6-10$ $\mu \mathrm{m}(\mathrm{L} \times \mathrm{W})$ (Fig. 31). In transverse fractures, rectangularshaped epithallial cells occurred in one layer (Fig. 31).
Epithallial cells measured 3-4×4-8 $\mu \mathrm{m}(\mathrm{L} \times \mathrm{W})$ (Fig. 31). In surface view epithallial cells were flat (Fig. 32) or in some cases with rim-like edges for the loss of roofs (Fig. 33).

REPRODUCTIVE ANATOMY: No gametangial conceptacles were observed. Tetrasporangial uniporate conceptacles were raised and their chambers measured $75-80 \times 230-275 \mu \mathrm{m}$ 

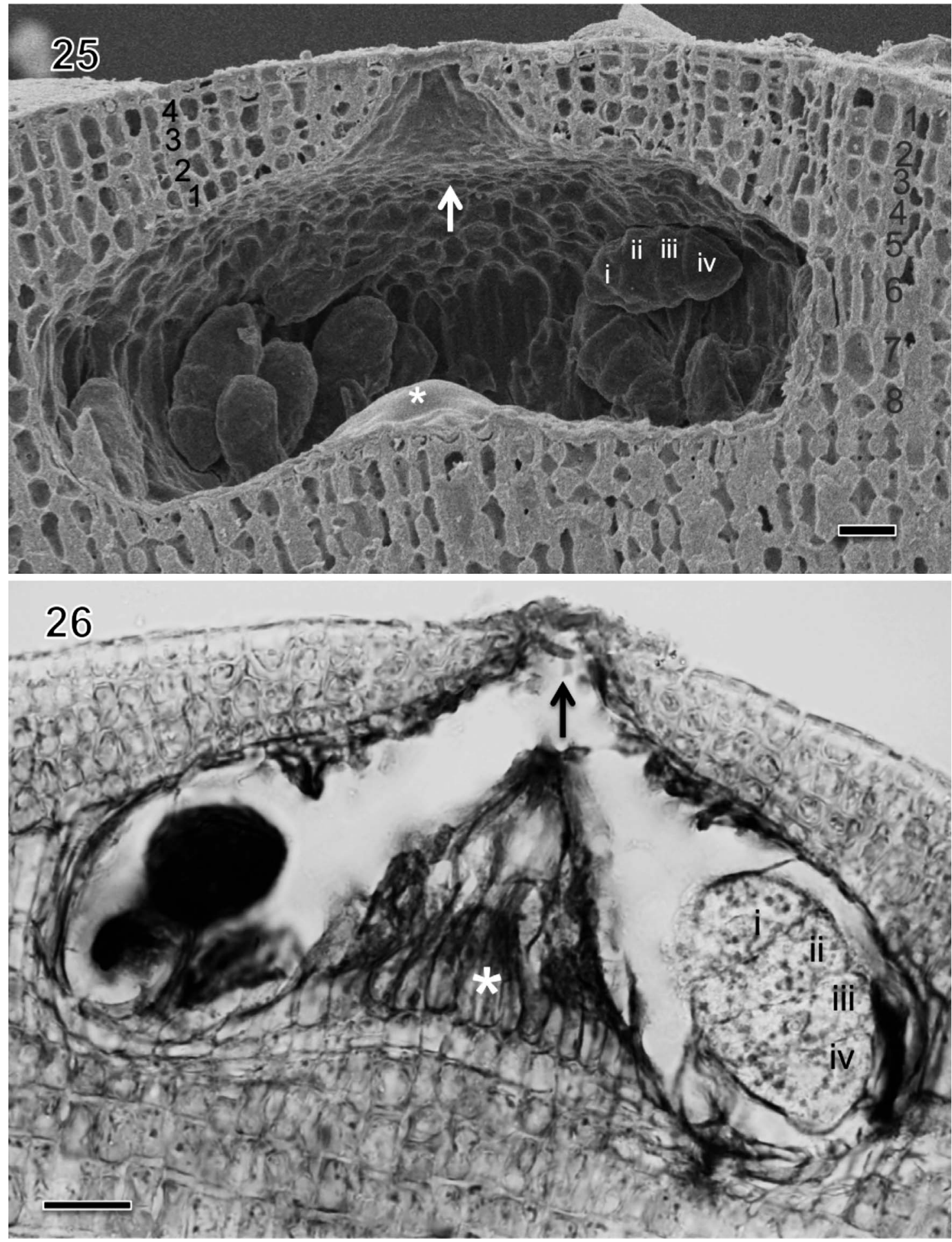

Figs 25, 26. Lithophyllum platyphyllum tetrasporangial conceptacle morpho-anatomy (SEM unless specified), US 170946.

Fig. 25. Transverse fracture of thallus showing tetrasporangial conceptacle with central columella (asterisk) and roof of four to five cell layers (black numbers). This tetrasporangial conceptacle occupied eight cell layers from conceptacle surface to base (grey numbers). Tetrasporangia (count in Roman numbers) and tapering shape of pore canal (arrow) visible. Scale bar $=20 \mu \mathrm{m}$.

Fig. 26. Histological view showing slightly protruding uniporate conceptacle containing tetrasporangia (count in Roman numbers), columella (asterisk) and pore canal blocked by mucilage plug (arrow). Scale bar $=20 \mu \mathrm{m}$. 


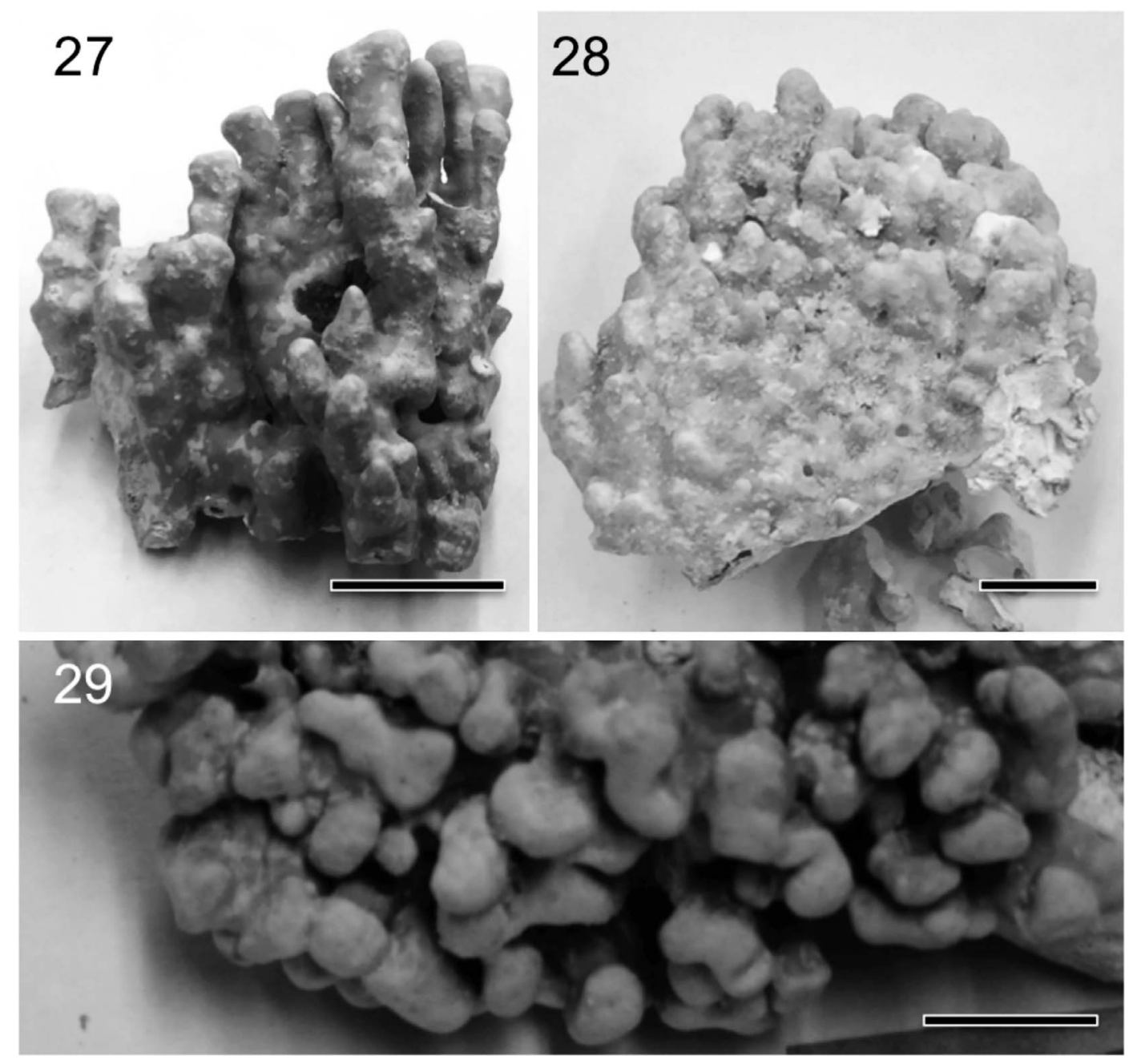

Figs 27-29. Lithophyllum neocongestum habit (Caribbean Sea: Panama and Barbados). Scale bars $=1 \mathrm{~cm}$.

Fig. 27. Lateral view of holotype specimen (US 223011) with fused columnar branches, some dichotomously branched.

Fig. 28. Lateral view of isotype specimen (NCU 598862) with free columnar branches.

Fig. 29. Surface view of specimen with columnar branches, some with expanded tips. US 169412.

$(\mathrm{L} \times \mathrm{W})$ (Fig. 34). Tetrasporangial conceptacle roofs were comprised of four to five cells (Fig. 34), the pore canal was tapered (Fig. 34) and the base of the pore canal lacked a rim. The conceptacle chamber floor was 7-10 cells below the surrounding thallus surface and comprised a central columella (Fig. 34, 35) formed by pre-existing perithallial filaments two to three cells thick. See Table 1 for tetrasporangia dimensions (Fig. 35).

DISTRIBUTION: Panama and Barbados.

\section{Lithophyllum pseudoplatyphyllum J.J.Hernandez-Kantun, W.H.Adey \& P.W.Gabrielson, sp. nov.}

(Figs 36-45)

DIAGNOSIS: Nongeniculate coralline with fruticose columnar to foliose branched thalli. Colour dark pink to purple. Thallus monomerous with noncoaxial hypothallium. Elongate perithallium cells measured $12-25 \times 6-12 \mu \mathrm{m}(\mathrm{L} \times \mathrm{W})$. Epithallial cells occurred in one layer. Trichocytes, primary and secondary pit connections present. Uniporate tetrasporangial conceptacles were raised and the chambers measured 70-80 × 125-200 $\mu \mathrm{m}(\mathrm{L} \times \mathrm{W})$. Tetrasporangia measured $50-80 \times 18-25 \mu \mathrm{m}(\mathrm{L} \times \mathrm{W})$. Tetrasporangial chamber roof formed by five to seven cells and 13-14 cells below the thallus surface. Thallus monoecious containing both spermatangial and carposporangial conceptacles. Spermatangial chambers measured 30-50×300$450 \mu \mathrm{m}(\mathrm{L} \times \mathrm{W})$. Carposporangial conceptacle chambers measured $100-140 \times 150-200 \mu \mathrm{m}(\mathrm{L} \times \mathrm{W})$.

HOLOTYPE: US 170943; 21 July 1972; East Point, St. Croix, US Virgin Islands; shallow subtidal, 0-3-m depth; leg. W. H. Adey (Fig. 36).

TYPE LOCALITY: East Point, Saint Croix, US Virgin Islands.

ETYMOLOGY: The epithet pseudoplatyphyllum is divided in three words: pseudo of Greek origin meaning false, platy of Greek origin meaning broad, wide, level, flat and phyllum of Greek origin meaning leaf (Brown 1956). The word pseudo is used in conjunction with the term platyphyllum to indicate the close phylogenetic relationship with Lithophyllum platyphyllum. 

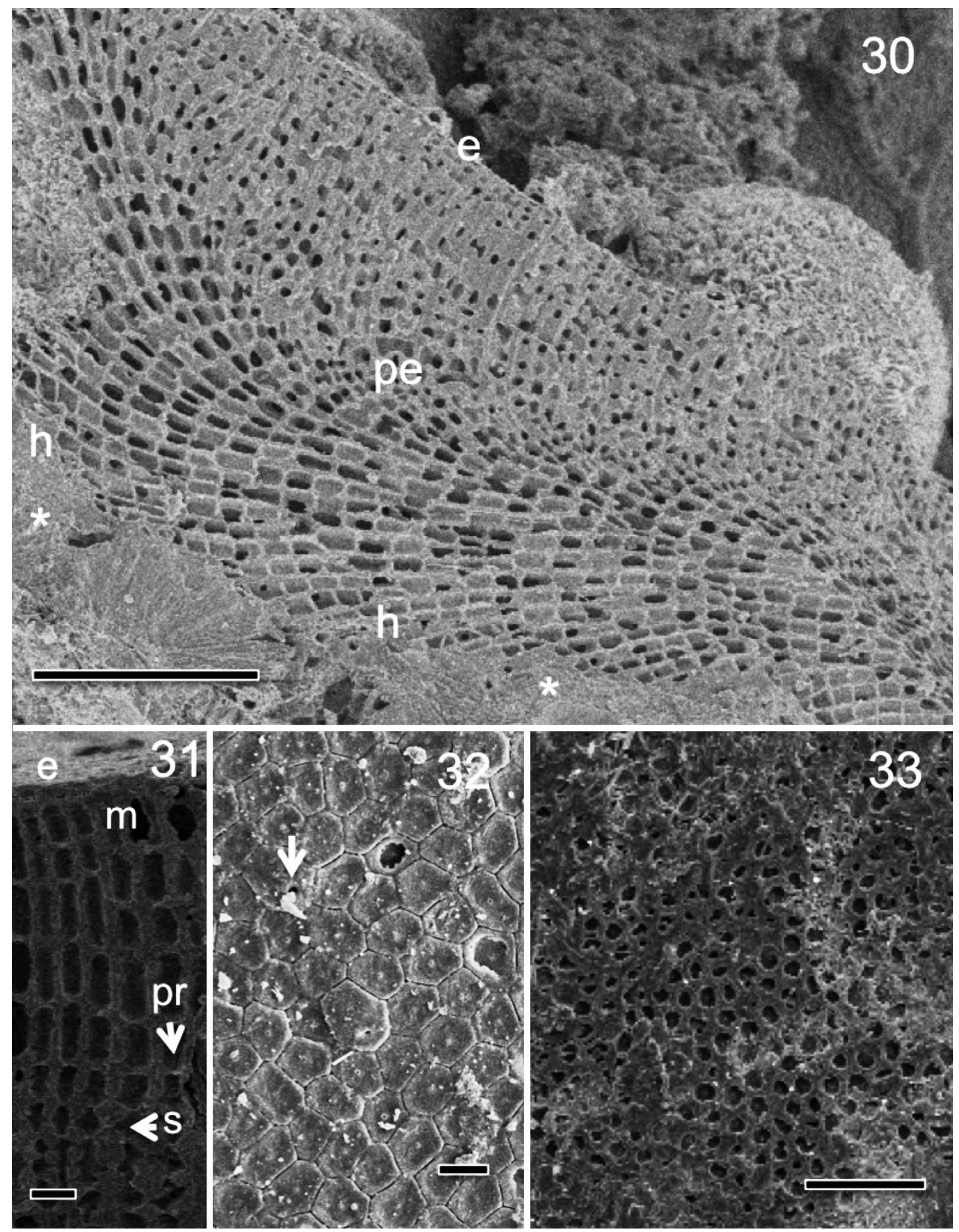

Figs 30-33. Lithophyllum neocongestum anatomy under SEM (Caribbean Sea: Panama and Barbados).

Fig. 30. Transverse fracture of thallus showing monomerous hypothallus (h) growing on substratum $(*)$; epithallium (e) and perithallium (pe) visible. US 169412. Scale bar $=100 \mu \mathrm{m}$

Fig. 31. Transverse fracture of thallus showing single epithallial cell layer (e) and meristematic cell (m); primary (pr) and secondary (s) pit connection visible. US 223011. Scale bar $=10 \mu \mathrm{m}$

Fig. 32. Surface view of complete epithallial cell roofs and opening of trichocyte (arrow). NCU 598862. Scale bar $=10 \mu \mathrm{m}$.

Fig. 33. Surface view of epithallial cells with lost roofs. US 169412. Scale bar $=50 \mu \mathrm{m}$. 

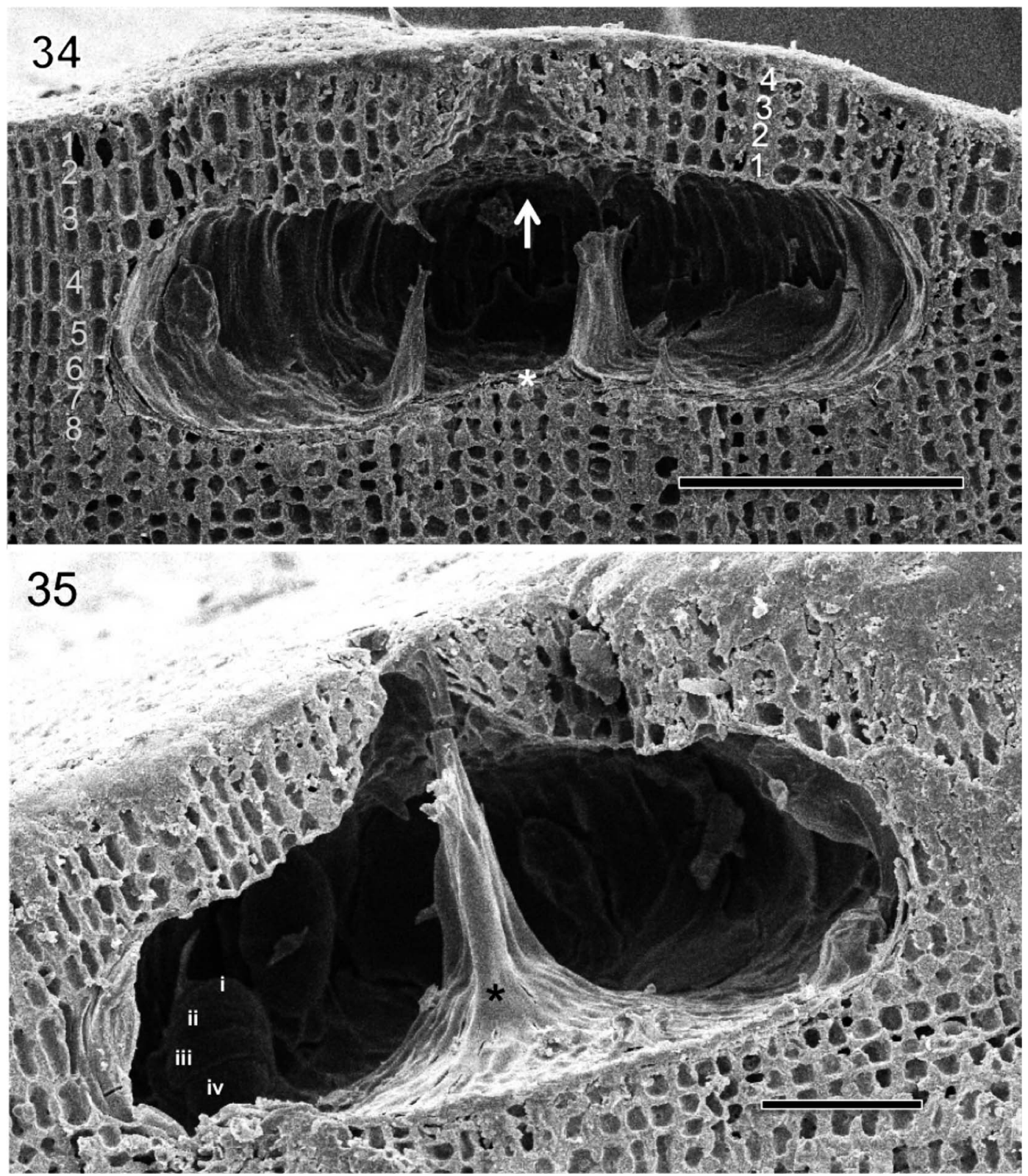

Figs 34, 35. Lithophyllum neocongestum tetrasporangia morphoanatomy under SEM. US 223011.

Fig. 34. Transverse fracture of thallus showing tetrasporangial conceptacle with central columella (asterisk) and roof of four cell layers (white numbers). This tetrasporangial conceptacle occupied eight cell layers from conceptacle surface to base (grey numbers). Pore canal with tapering shape (arrow). Scale bar $=100 \mu \mathrm{m}$.

Fig. 35. Transverse fracture of thallus showing tetrasporangia (count in Roman numbers) with columella (asterisk). Scale bar $=50 \mu \mathrm{m}$.

DNA SEQUENCES: A 490-bp $r b c \mathrm{~L}$ sequence (GenBank KX020480) and a 454-bp psbA sequence (GenBank KX020454) from the holotype of Lithophyllum pseudoplatyphyllum were obtained. Two psbA sequences from 398 to 453 bp in length (GenBank KX020450 and KX020451) were obtained from specimens from St. Croix (US Virgin Islands,). The sequences were identical.

HABITAT AND HABIT: The species occurred on exposed reef crests and subtidal to 3-m depth. Thalli were encrusting smooth to fruticose branched and dark pink to purple.
Branches varied from columnar to foliose, $0.3-0.5 \mathrm{~cm}$ thick (Figs 36, 37).

VEGETATIVE ANATOMY: Thallus monomerous with noncoaxial hypothallium (Fig. 38). Hypothallial cells measured 20-30 $\times 9-15 \mu \mathrm{m}(\mathrm{L} \times \mathrm{W})($ Fig. 38). The perithallium comprised elongate cells that measured $12-25 \times 6-12 \mu \mathrm{m}(\mathrm{L} \times \mathrm{W})($ Fig. 38). Primary and secondary pit connections were observed (Fig. 39); trichocytes were rare. Square to elongate meristematic cells measured 6-10 × 6-18 $\mu \mathrm{m}(\mathrm{L} \times \mathrm{W})($ Fig. 39). In surface view epithallial cells were $8-10 \mu \mathrm{m}$ wide (Fig. 40), 


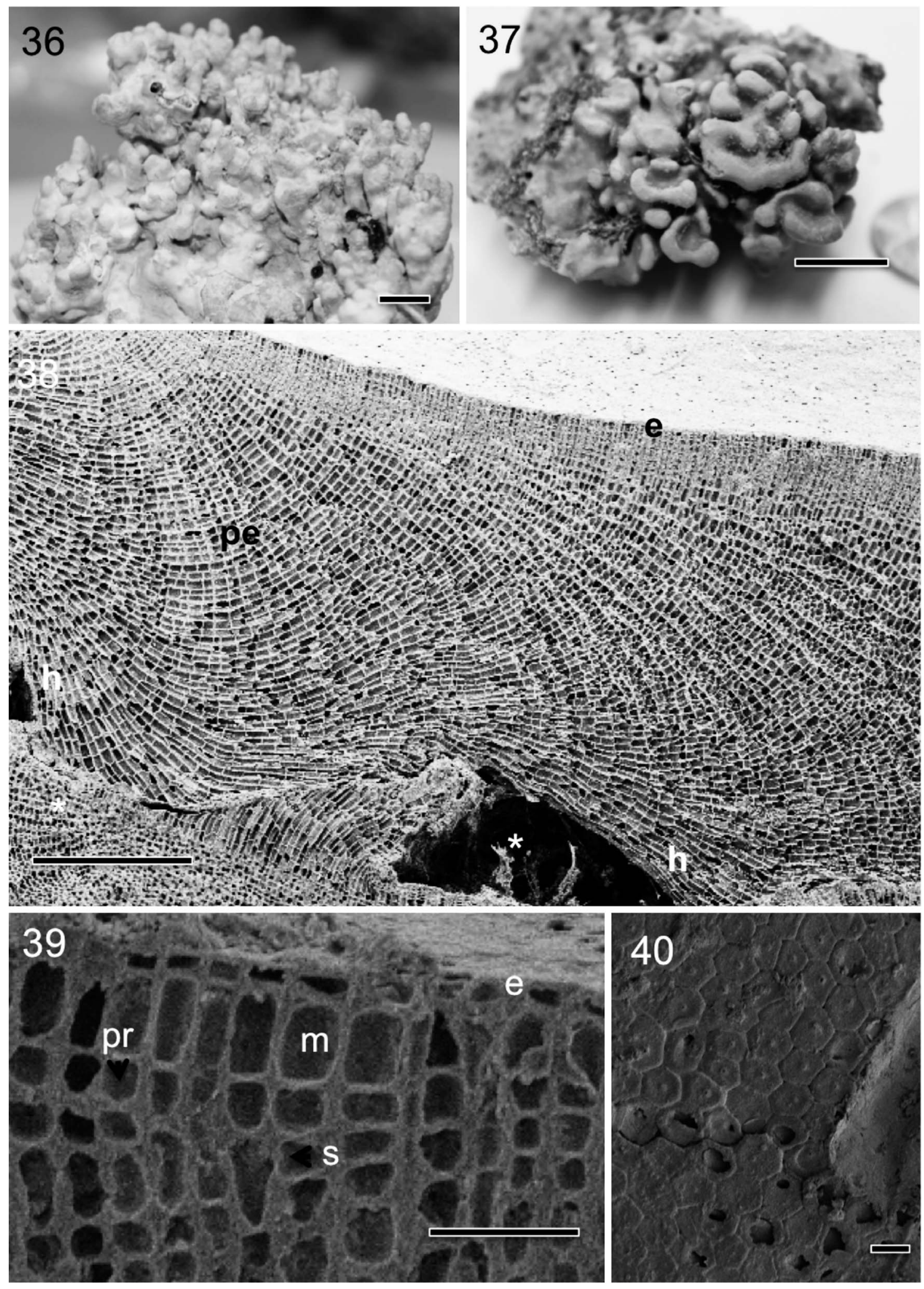

Figs 36-40. Lithophyllum pseudoplatyphyllum sp. nov. vegetative gross morphology and anatomical details (SEM unless specified). Caribbean Sea: St. Croix.

Fig. 36. Lateral view of holotype (US 170943) with fused foliose branches. Scale bars $=1 \mathrm{~cm}$.

Fig. 37. Surface view of US 169406 (S41) with columnar branches. Scale bars $=1 \mathrm{~cm}$.

Fig. 38. Transverse fracture of thallus showing monomerous hypothallus (h) growing on substratum (*); epithallium (e) and perithallium (pe). US 169406 (S40). Scale bar $=200 \mu \mathrm{m}$.

Fig. 39. Transverse fracture of thallus showing single epithallial cell layer (e) and meristematic cell (m); primary (pr) and secondary (s) pit connection. US 169406 (S41). Scale bar $=20 \mu \mathrm{m}$.

Fig. 40. Surface view of epithallial cells. US 169406 (S41). Scale bar $=10 \mu \mathrm{m}$. 


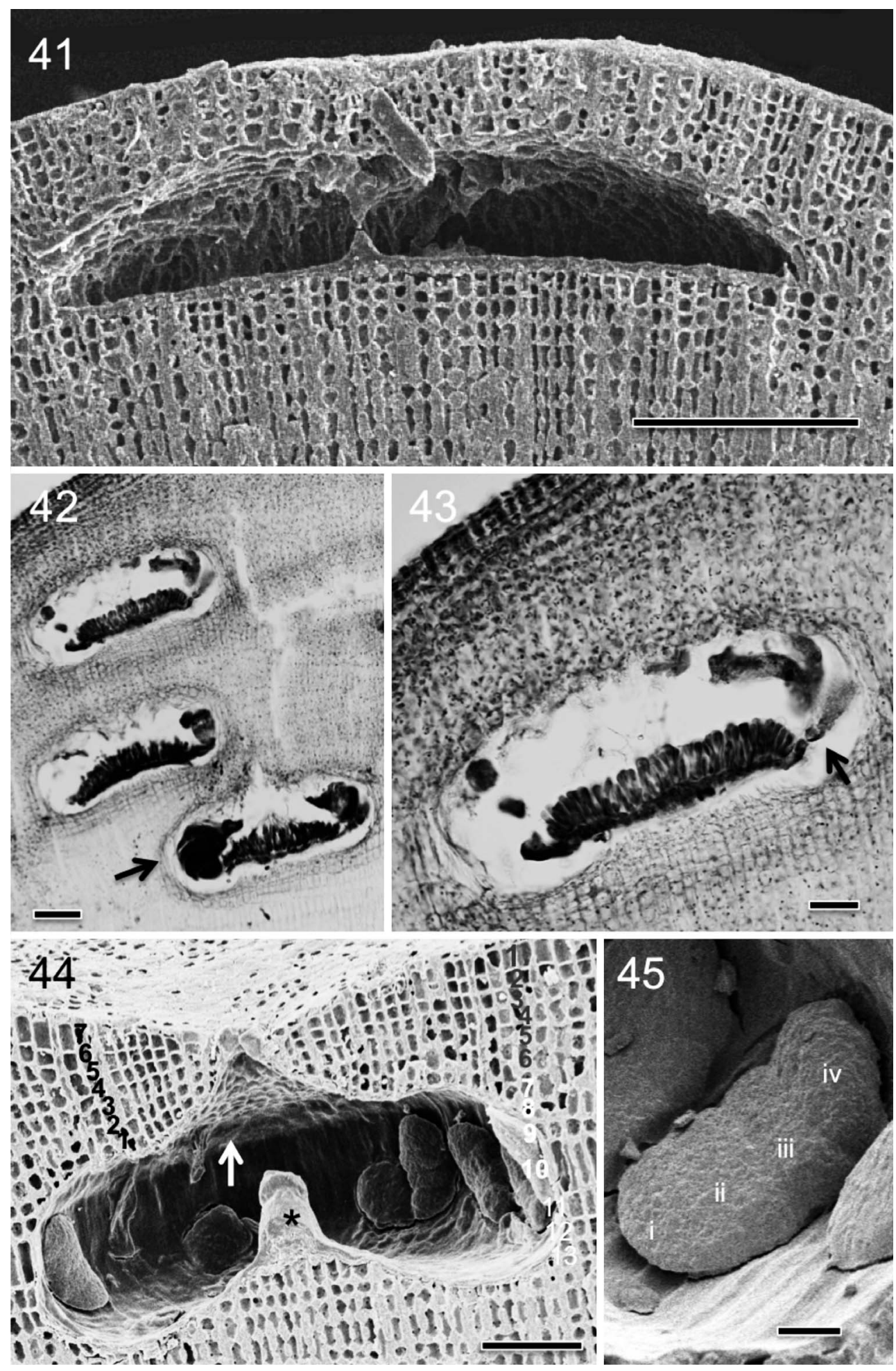

Figs 41-45. Lithophyllum pseudoplatyphyllum reproductive morphoanatomy (SEM unless specified).

Fig. 41. Transverse fracture of thallus showing spermatangial conceptacle without columella. US $169406(\mathrm{~S} 40)$. Scale bar $=100 \mu \mathrm{m}$.

Fig. 42. Histological view showing carposporangial conceptacles, some buried and with carpospores visible (arrow). US 170943. Scale bar $=50 \mu \mathrm{m}$.

Fig. 43. Histological view showing a close-up of carpospores (arrow) and thin filaments on the conceptacle floor. US 170943 . Scale bar $=20$ $\mu \mathrm{m}$.

Fig. 44. Transverse fracture of thallus showing tetrasporangial conceptacle with central columella (asterisk) and roof of seven cell layers (black numbers). This tetrasporangial conceptacle occupied 13 cell layers from conceptacle surface to base (grey and white numbers). Pore canal visible with tapering shape (arrow). US 169406 (S41). Scale bar $=50 \mu \mathrm{m}$.

Fig. 45. Transverse fracture of thallus showing tetrasporangia (count in Roman numbers). US 169406 (S41). Scale bar $=10 \mu \mathrm{m}$. 
whereas in transverse fracture, one layer of rectangular epithallial cells were 3-7 × 6-10 $\mu \mathrm{m}(\mathrm{L} \times \mathrm{W})($ Fig. 39). In surface view epithallial cells were flat (Fig. 40).

REPRODUCTIVE ANATOMY: The same holotype thallus contained spermatangial and carposporangial conceptacles. Nevertheless, for the isotype only spermatangial conceptacles were observed. In transverse fracture, spermatangial chamber measured 30-50 × 300-450 $\mu \mathrm{m}(\mathrm{L} \times \mathrm{W})($ Fig. 41). Spermatangial conceptacle roofs were comprised of three to six cells (Fig. 41). The spermatangial chamber floors were seven to nine cells below the surrounding thallus surface and without a visible columella (Fig. 41). Four layers of male conceptacles were observed buried under the fresh/top layer of conceptacles. In transverse sections, carposporangial chambers measured 100-140× 150-200 $\mu \mathrm{m}(\mathrm{L} \times \mathrm{W})($ Figs 42, 43). Carposporangial conceptacle roofs were comprised of 4-11 cells (Fig. 43). Carposporangial conceptacle floors were 14-15 cells below the surrounding thallus surface devoid of columella but with short filaments (Figs 42, 43). Carpospores 24-27 $\mu \mathrm{m}$ in diameter and with iregular shape (Figs 42, 43).

Tetrasporangia were raised and their chamber measured $70-80 \times 125-200 \mu \mathrm{m}(\mathrm{L} \times \mathrm{W})($ Fig. 44). Tetrasporangial conceptacle roofs were comprised of five to seven cells. The pore canal was tapered (Fig. 44) and the base of the pore canal lacked a rim. The conceptacle chamber floor was 13-14 cells below the surrounding thallus surface and comprised a central columella formed by pre-existing perithallial filaments two to three cells thick (Fig. 44). See Table 1 for tetrasporangia dimensions (Fig. 45).

DISTRIBUTION: US Virgin Islands.

\section{DISCUSSION}

\section{Synonymy of nongeniculate coralline species}

This study refutes the proposed synonymy of Tamega et al. (2014) of the branched, columnar Caribbean Sea species, Lithophyllum congestum $(=$ L. kaiseri), under the lamellate Mediterranean species, L. stictaeforme, by using DNA sequences as opposed to morphoanatomical comparisons. The latter have frequently resulted in incorrect taxonomic conclusions for both geniculate (Gabrielson et al. 2011; Hind et al. 2014a, 2015) and nongeniculate corallines (Kato et al. 2013; Sissini et al. 2014; Hernandez-Kantun et al. 2015), once DNA sequences have been applied. Both Kato et al. (2013) and Sissini et al. (2014) recommended avoiding a previously common procedure of placing in synonymy species of nongeniculate corallines with grossly different morphologies, such as lamellate vs branched columnar thalli. We concur and extend this also to any anatomical characters when unsupported by DNA sequences.

\section{Lithophyllum kaiseri}

The proposed synonymy of $L$. congestum and L. kaiseri is based on the identical $r b c \mathrm{~L}$ sequences between the isolectotype of L. kaiseri (NY00945463) and the holotype collection of $L$. congestum (TRH A23-1381). We were unable, however, to obtain comparable DNA sequences with the same marker for the L. kaiseri lectotype (TRH A20-1264) and isolectotype (NY00945463). The collection data of the specimens is the same, but there are some morphoanatomical discrepancies in the descriptions provided by Basso et al. (2015) and herein with respect to thallus construction (monomerous vs dimerous), presence/absence of a columella in conceptacles and whether conceptacles are flush with the thallus surface or raised. Reports of both thallus constructions in the same specimen for L. frondosum (Dufour) G.Furnari, Cormaci \& Alongi (Furnari et al. 1996) and the inclusion of both constructions in the most recent description of the genus (Harvey et al. 2009) showed that this is not an isolated event. All other observations between the lectotype and isolectotype were coherent, and all measurements of the same structures overlap/matched. But all of these are based on only single specimens; thus our knowledge of the infraspecific variation is virtually unknown in nearly all of the Lithophyllum species described by Basso et al. (2015) or herein. On the basis of DNA sequences, we do know that specimens with the same $p s b \mathrm{~A}$ sequences occur widely in the tropical Indo-West Pacific, Red Sea and Caribbean Sea, and until demonstrated otherwise, the best available name is L. kaiseri.

\section{Lithophyllum species diversity}

Our results for branched Lithophyllum species in the Caribbean Sea lead to similar conclusions as those of Basso et al. (2015) for morphologically similar Lithophyllum species in the Red Sea: there is a large amount of cryptic or pseudocryptic diversity that is evident when assessed by DNA sequencing compared with traditional morphoanatomical analyses. Since the mid-1970s all branched Caribbean Lithophyllum specimens had been considered to belong to a single species, $L$. congestum (Steneck \& Adey 1976), just as all branched Red Sea species had been called L. kotschyanum (Basso et al. 2015). On the basis of these two tropical regions and a recent treatment of European temperate Lithophyllum species (Hernandez-Kantun et al. 2015), we hypothesize that in all other similar biogeographic provinces worldwide, DNA sequencing will reveal additional undescribed species of Lithophyllum. Because species diversity likely is two to four times greater in each geographic region, an integrative approach is essential that includes: (1) sequencing contemporary specimens to assess the diversity; (2) sequencing type or, far less preferably, topotype specimens (see Hind et al. 2015 regarding problems with topotype specimens) to correctly apply names; and (3) performing morphoanatomical observations on sequenced specimens. We argue that it is this sole approach that will allow the determination of which morphoanatomical features are diagnostic and which are variable within species. However, this approach requires a much greater collecting effort when the species diversity is several times higher than is generally believed. This systematic integrative approach has not been applied comprehensively in any biogeographic province where coralline algae are found, including Lithophyllum species.

In the Caribbean Sea, four branched Lithophyllum species were found under one name, L. congestum ( $=$ L. kaiseri), and a name that had been placed in synonymy under $L$. congestum, L. platyphyllum, applies to one of these four species. On the basis of DNA sequence data obtained for other type 
specimens from the Caribbean Sea, validly published names are not available for the two newly described species, $L$. pseudoplatyphyllum and L. neocongestum. Although we can distinguish these species using DNA sequences, we currently have no real understanding of their ecology, biogeography or morphoanatomy. Our sample sizes are too low $(n=3-9)$ for any meaningful comparisons, although these numbers are typical for the vast majority of coralline morphoanatomical studies. Even with larger sample sizes, in the absence of DNA sequence data to confirm specimen identification and thus intraspecific morphoanatomical variation, we cannot improve our understanding of these species. It will require a significant sampling and sequencing effort, with detailed attention to the habitat of each specimen, to determine if these species have distinct ecological niches or whether they can be distinguished on any morphoanatomical basis.

\section{Trichocytes}

It is premature to speculate which characters or combinations of characters may be diagnostic for lineages within Lithophyllum on the basis of the aforementioned problems of small sample sizes coupled with greater species diversity. However, it is intriguing to note that trichocytes are present in all tropical Red Sea and Caribbean Sea species, but not in temperate European species (Basso et al. 2015; HernandezKantun et al. 2015). Whether this is true for all other tropical vs temperate biogeographic provinces containing Lithophyllum species needs to be investigated, as does the utility of this character for uniting clades of Lithophyllum species.

\section{Widespread nongeniculate coralline species}

The most interesting and unexpected result of this study was the occurrence of a single species of branched Lithophyllum $(L$. kaiseri) with a widespread, nearly pantropical distribution (absent from the tropical eastern Pacific). Sissini et al. (2014) and van der Merwe et al. (2015) have questioned the reported widespread distributions of nongeniculate corallines, particularly in different oceans or biogeographic provinces, on the basis only of morphoanatomical similarities. To date these distributions have not been supported by DNA sequence data. Nevertheless, both plastid markers used in this study indicate that L. kaiseri is widespread in the Caribbean Sea (St. Croix, St. Barthelemy, Jamaica, Cuba, Martinique), the Red Sea (Gulf of Suez and Gulf of Aqaba) and the Indo-West Pacific Ocean (Madagascar; Okinawa, Japan; GBR Australia). An analysis of the population structure and connectivity patterns using more variable markers such as the cox 1 gene, the internal transcribed spacer ribosomal DNA and the cox 2-3 spacer, or even specific microsatellites (Hernandez-Kantun et al. 2014; Pardo et al. 2014; Peña et al. 2014, 2015a) would help to understand gene flow within this species. Moreover, the widely distributed L. kaiseri occurs in a clade with the northern Indian Ocean L. socotraense with strong support, whereas L. yemenense occurs in a moderately to strongly supported clade with the remaining three Caribbean branched species, two specimens called L. kotschyanum from Okinawa and several other branched species from the Philippines, Fiji and Vanuatu. The relationships among branched tropical Lithophyllum species appear to be complex, as are their biogeographic patterns.

\section{ACKNOWLEDGEMENTS}

Foremost, we dedicate this work to our beloved friend and colleague, Dr. Rafael Riosmena Rodriguez, who suddenly passed away. We thank collectors Robert Steneck, Will Schmidt, Daniela Gabriel, Thomas Sauvage, Suzanne Fredericq, Sara Kaleb, Annalisa Falace and Bryan Wysor. The help of curators at NY and TRH is greatly appreciated for providing fragments or loans of the type material. J.J. H.-K. thanks the Smithsonian Institution for a postdoctoral fellowship, a fellowship to attend the 2012 Tropical Field Phycology course at the Smithsonian's Bocas del Toro Research Station and the help of staff at National Museum of Natural History Laboratories of Analytical Biology. Collections from Red Sea localities were supported by National Science Foundation (NSF) DEB-0919508; some Panama collections were supported by NSF DEB-0742437. DNA extraction and sequencing performed by J.R.H. were funded by the generous support from a private family trust (P.W.G.). V.P.F. acknowledges support by Universidade da Coruña and by the postdoctoral program Axudas de apoio á etapa inicial de formación postdoutoral, Plan I2C (Xunta de Galicia). The specimen PC0165991 was collected during the Atimo Vatae expedition (principal investigator Philippe Bouchet), funded by the Total Foundation, Prince Albert II of Monaco Foundation, and Stavros Niarchos Foundation under "Our Planet Reviewed", a joint initiative of Muséum National d'Histoire Naturelle and Pro Natura International in partnership with Institut d'Halieutique et des Sciences Marines, University of Toliara and the Madagascar bureau of Wildlife Conservation Society. The Institut de Recherche pour le Développement deployed its research catamaran Antéa.

\section{SUPPLEMENTARY DATA}

Supplementary data associated with this article can be found online at http://dx.doi.org/10.2216/16-7.1.s1.

\section{REFERENCES}

AdEy W.H. 1978. Coral reef morphogenesis: a multidimensional model. Science 202: 831-837.

Adey, W.H. 1986. Coralline algae as indicators of sea-level. In: Sealevel research: a manual for the collection and evaluation of data (Ed. by O. van de Plassche), pp. 229-280. Geo Books, Norwich, UK.

ADEY W.H. 1998. Coral reefs: algal structured and mediated ecosystems in shallow, turbulent, alkaline waters. Journal of Phycology 34: 393-406.

Adey W.H. \& Adey P. 1973. Studies on the biosystematics and ecology of the epilithic crustose Corallinaceae of the British Isles. British Phycological Journal 8: 343-407.

Adey W.H., Hernandez-Kantun J.J., Johnson G. \& Gabrielson P.W. 2015. DNA sequencing, anatomy, and calcification patterns support a monophyletic, subarctic, carbonate reef-forming Clathromorphum (Hapalidiaceae, Corallinales, Rhodophyta). Journal of Phycology 51: 189-203.

Athanasiadis A. 1999. The taxonomic status of Lithophyllum stictaeforme (Rhodophyta, Corallinales) and its generic position in light of phylogenetic considerations. Nordic Journal of Botany 19: 735-745. 
Ballantine D.L., Athanasiadis A. \& Ruiz H. (2011). Notes on the benthic marine algae of Puerto Rico. X. Additions to the flora. Botanica Marina 54: 293-302.

Basso D., Caragnano A. \& Rodondi G. 2014. Trichocytes in Lithophyllum kotschyanum and Lithophyllum spp. (Corallinales, Rhodophyta) from the NW Indian Ocean. Journal of Phycology 50: 711-717.

Basso D., Caragnano A., Le Gall L. \& Rodondi G. 2015. The genus Lithophyllum in the north-western Indian Ocean, with description of $L$. yemenense sp. nov., L. socotraense sp. nov., $L$. subplicatum comb. et stat. nov., and the resumed L. affine, $L$. kaiseri, and L. subreduncum (Rhodophyta, Corallinales). Phytotaxa 208: 183-200.

Brown R.W. 1956. Composition of scientific words. Smithsonian Institution Press, Washington, DC. 882 pp.

FosLie M. 1899. Some new or critical lithothamnia. Det Kongelige Norske Videnskabers Selskabs Skrifter 1898(6): 1-19.

Foslie M. 1900. Revised systematical survey of the Melobesieae. Det Kongelige Norske Videnskabers Selskabs Skrifter 1900 (5): 122.

Foslie M. \& Howe M.A. 1906. New American coralline algae. Bulletin of the New York Botanical Gardens 4: 128-136.

Freshwater D.W. \& Rueness J. 1994. Phylogenetic relationships of some European Gelidium (Gelidiales, Rhodophyta) species based upon $r b c \mathrm{~L}$ nucleotide sequence analysis. Phycologia 33: 187-194.

Furnari G., Cormaci M. \& Alongi G. 1996. Lithophyllum frondosum (Dufour) comb. nov. (Corallinaceae, Rhodophyta): the species to which Mediterranean 'Pseudolithophyllum expansum' should be referred. European Journal of Phycology 31: 117122.

Gabrielson P.W., Miller K.A., \& Martone P.T. 2011. Morphometric and molecular analyses confirm two distinct species of Calliarthron (Corallinales, Rhodophyta), a genus endemic to the Northeast Pacific. Phycologia 50: 293-316.

Harvey A., Woelkerling W.J. \& Millar A.J.K. 2009. The genus Lithophyllum (Lithophylloideae, Corallinaceae, Rhodophyta) in south-eastern Australia, with the description of L. riosmenae, sp. nov. Australian Systematic Botany 22: 296-317.

Hernández-Kantún J.J., Riosmena-Rodríguez R., Adey W.H. \& Rindi F. 2014. Analysis of the cox 2-3 spacer region for population diversity and taxonomic implications in rhodolithforming species (Rhodophyta, Corallinales). Phytotaxa 190: 331354.

Hernández-Kantún J.J., Rindi F., Adey H.W., Le Gall L. Peña V. \& Gabrielson P. (2015). Sequencing type material resolves the identity and distribution of the generitype Lithophyllum incrustans, and related European species L. hibernicum and $L$. bathyporum (Corallinales, Rhodophyta). Journal of Phycology 51: 791-807.

HeYdrich F. 1897a. Melobesiae. Berichte der deutsche botanischen Gesellschaft 15: 403-420, pl XVIII.

Heydrich F. 1897b. Corallinaceae, insbesondere Melobesieae. Berichte der deutsche botanischen Gesellschaft 15: 34-70, 3 figs, pl III.

Hind K.R., Gabrielson P.W., Lindstrom S.C. \& Martone P.T. 2014a. Misleading morphologies and the importance of sequencing type specimens for resolving coralline taxonomy (Corallinales, Rhodophyta): Pachyarthron cretaceum is Corallina officinalis. Journal of Phycology 50: 760-764.

Hind K.R., Gabrielson P.W. \& Saunders G.W. 2014b. Molecularassisted alpha taxonomy reveals pseudocryptic diversity among species of Bossiella (Corallinales, Rhodophyta) in the eastern Pacific Ocean. Phycologia 53: 443-456.

Hind K.R., Miller K.A., Young M., Jensen C., Gabrielson P.W. \& Martone P. 2015. Resolving cryptic species of Bossiella (Corallinales, Rhodophyta) using contemporary and historical DNA. American Journal of Botany 102: 1-19.

Huelsenbeck J. P. \& RonQuist F. 2001. MRBAYES: Bayesian inference of phylogeny. Bioinformatics 17: 754-755.

Hughey J.R. \& Gabrielson P.W. 2012. Comment on "Acquiring DNA sequence data from dried archival red algae (Florideophyceae) for the purpose of applying available names to contemporary genetic species: A critical assessment". Botany 90: 1191-1194.
Kato A., Baba M. \& Suda S. 2013. Taxonomic circumscription of heterogeneous species Neogoniolithon brassica-florida (Corallinales, Rhodophyta) in Japan. Phycological Research 61: 15-26.

Littler D.S. \& LitTler M.M. 2000. Caribbean reef plants. An identification guide to the reef plants of the Caribbean, Bahamas, Florida and Gulf of Mexico. Offshore Graphics Press, Washington. $542 \mathrm{pp}$.

McNeill J., Barrie F.R., Buck W.R., Demoulin V., Greuter W., Hawksworth D.L., Herendeen P.S., Knapp S., Marhold K., Prado J., Prud'homme Van Reine W.F., Smith G.F., Wiersema J.H. \& Turland N.J. 2012. International Code of Nomenclature for algae, fungi, and plants (Melbourne Code) adopted by the Eighteenth International Botanical Congress Melbourne, Australia, July 2011. Regnum Vegetabile 154. A.R.G. Gantner Verlag KG. ISBN 978-3-87429-425-6.

Pardo C., Peña V., Bárbara I., Valero M. \& Barreiro R. 2014 Development and multiplexing of the first microsatellite markers in a coralline red alga (Phymatolithon calcareum, Rhodophyta). Phycologia 53: 474-479.

Peña V., Hernandez-Kantun J.J., Grall J., Pardo C., Lopez L., Bárbara I., Le Gall L. \& Barreiro R. 2014. Detection of gametophytes in the maerl-forming species Phymatolithon calcareum (Melobesioideae, Corallinales) assessed by DNA barcoding. Cryptogamie, Algologie 35: 15-25.

Peña V., De Clerck O., Afonso-Carrillo J., Ballesteros E. Bárbara I., Barreiro R. \& Le Gall L. 2015a. An integrative systematic approach to species diversity and distribution in the genus Mesophyllum (Corallinales, Rhodophyta) in Atlantic and Mediterranean Europe. European Journal of Phycology 50: 20-36.

Peña V., Pardo C., Lopez L., Carro B., Hernandez-Kantun J.J., Adey W.H. Bárbara I., Barreiro R. \& Le Gall L. 2015b. Phymatolithon lusitanicum sp. nov. (Hapalidiales, Rhodophyta): the third most abundant maerl-forming species in the Atlantic Iberian Peninsula. Cryptogamie, Algologie 36: 1-31.

Rambaut A. \& Drummond A.J. 2007. Tracer v1.4. http://beast.bio. ed.ac.uk/Tracer.

Silvestro D. \& MichalaK I. 2011. RAxMLGUI: a graphical frontend for RAxML. https://sites.google.com/site/raxmlgui/.

Sissini M.N., De Oliveira M.C., Gabrielson P.W., Robinson N.M., Okolodkov Y.B., Riosmena-Rodriguez R. \& Horta P.A. 2014. Mesophyllum erubescens (Corallinales, Rhodophyta) so many species in one epithet. Phytotaxa 190: 299-319.

Steneck R.S. \& Adey W.H. 1976. The role of environment in control of morphology in Lithophyllum congestum, a Caribbean algal ridge builder. Botanica Marina 19: 197-215.

Tâmega F.T.S., Riosmena-Rodrigues R., Mariath R. \& FigueirEDO M.A.O. 2014. Nongeniculate coralline red algae (Rhodophyta: Corallinales) in coral reefs from Northeastern Brazil and a description of Neogoniolithon atlanticum sp. nov. Phytotaxa 190: 277-298.

Tamura K., Peterson D., Peterson N., Stecher G., Nei M. \& KumAR S. 2011. MEGA5: molecular evolutionary genetics analysis using maximum likelihood, evolutionary distance, and maximum parsimony methods. Molecular Biology and Evolution 28: 2731-2739.

Thiers B. 2015 (continuously updated). Index Herbariorum: a global directory of public herbaria and associated staff. New York Botanical Garden's Virtual Herbarium. http://sweetgum. nybg.org/ih/.

van der Merwe E., Miklasz K., Channing A., Maneveldt G.W. \& GABRIELSON P.W. 2015. DNA sequencing resolves species of Spongites (Corallinales, Rhodophyta) in the Northeast Pacific and South Africa, including S. agulhensis sp. nov. Phycologia 54: 471-490.

Woelkerling W.J., Gustavsen G., Myklebost H.E., Prestø T., \& SÅSTAD S.M. 2005. The coralline red algal herbarium of Mikael Foslie: revised catalogue with analyses. Gunneria 77: 1-625.

Yoon H.S., Hackett J.D. \& Bhattacharya D. 2002. A single origin of the peridinin and fucoxanthin containing plastids in dinoflagellates through tertiary endosymbiosis. Proceedings of the National Academy of Sciences of the United States of America 99: 11724-11729.

Received 17 January 2016; accepted 24 May 2016 